\title{
THE LANDSCAPE OF ECONOMIC GROWTH: DO MIDDLE-INCOME COUNTRIES DIFFER?
}

Barry Eichengreen, Donghyun Park, and Kwanho Shin

NO. 517

August 2017
ADB ECONOMICS WORKING PAPER SERIES 
ADB Economics Working Paper Series

\section{The Landscape of Economic Growth: Do Middle-Income Countries Differ?}

Barry Eichengreen, Donghyun Park, and Kwanho Shin

No. 517 | August 2017
Barry Eichengreen (eichengr@berkeley.edu) is a professor at the Department of Economics, University of California Berkeley. Donghyun Park (dpark@adb.org) is a principal economist at the Economic Research and Regional Cooperation Department, Asian Development Bank. Kwanho Shin (khshin@korea.ac.kr) is a professor at the Department of Economics, Korea University.

This paper was prepared as background material for the Asian Development Outlook 2017. We thank Sul Wi Shin for her excellent research assistance and the Asian Development Bank for financial support. 
(C) (1)

(C) 2017 Asian Development Bank

6 ADB Avenue, Mandaluyong City, 1550 Metro Manila, Philippines

Tel +632632 4444; Fax +6326362444

www.adb.org

Some rights reserved. Published in 2017.

ISSN 2313-6537 (Print), 2313-6545 (e-ISSN)

Publication Stock No. WPS178959-2

DOI: http://dx.doi.org/10.22617/WPS178959-2

The views expressed in this publication are those of the authors and do not necessarily reflect the views and policies of the Asian Development Bank (ADB) or its Board of Governors or the governments they represent.

ADB does not guarantee the accuracy of the data included in this publication and accepts no responsibility for any consequence of their use. The mention of specific companies or products of manufacturers does not imply that they are endorsed or recommended by ADB in preference to others of a similar nature that are not mentioned.

By making any designation of or reference to a particular territory or geographic area, or by using the term "country" in this document, $A D B$ does not intend to make any judgments as to the legal or other status of any territory or area.

This work is available under the Creative Commons Attribution 3.0 IGO license (CC BY 3.0 IGO)

https://creativecommons.org/licenses/by/3.0/igo/. By using the content of this publication, you agree to be bound by the terms of this license. For attribution, translations, adaptations, and permissions, please read the provisions and terms of use at https://www.adb.org/terms-use\#openaccess

This CC license does not apply to non-ADB copyright materials in this publication. If the material is attributed to another source, please contact the copyright owner or publisher of that source for permission to reproduce it. ADB cannot be held liable for any claims that arise as a result of your use of the material.

Please contact pubsmarketing@adb.org if you have questions or comments with respect to content, or if you wish to obtain copyright permission for your intended use that does not fall within these terms, or for permission to use the ADB logo.

Notes:

1. In this publication, "\$” refers to US dollars.

2. ADB recognizes "China" as the People's Republic of China and "Korea” as the Republic of Korea.

3. Corrigenda to ADB publications may be found at http://www.adb.org/publications/corrigenda 


\section{CONTENTS}

TABLES

ABSTRACT

$\begin{array}{ll}\text { I. INTRODUCTION } & 1\end{array}$

$\begin{array}{ll}\text { II. DATA } & 2\end{array}$

III. BASICRESULTS

$\begin{array}{lll}\text { IV. } & \text { GROWTH ACCOUNTING }\end{array}$

V. SECTORAL COMPARISONS

$\begin{array}{ll}\text { VI. CRISES AND GROWTH } & 17\end{array}$

$\begin{array}{ll}\text { VII. CONCLUSIONS } & 21\end{array}$

$\begin{array}{lc}\text { APPENDIXES } & 23\end{array}$

$\begin{array}{ll}\text { REFERENCES } & 31\end{array}$ 


\section{TABLES}

$1 \quad$ Summary Statistics: Oil-Producing Countries Included 4

2 All Country and Decade Observation 6

$3 \quad$ Countries in the Low-Income Class at the Initial Year 8

$4 \quad$ Countries in the Low- and Middle-Income Class at the Initial Year 9

5 Countries in the Middle-Income Class at the Initial Year 10

$6 \quad$ Countries in the Middle- and High-Income Class at the Initial Year 11

$7 \quad$ Economic Factors that are Associated with Growth for Different Income Classes 13

8 Growth Accounting Decomposition of Aggregate Gross Domestic Product for Different Income Classes $\quad 14$

9 The Impact of Crises on Long-Run Growth 19

A1 Sources and Definitions of Variables 23

A2 All Country and Decade Observations: Oil Countries Excluded 24

A3 Countries in the Low-Income Class at the Initial Year: Oil Countries Excluded 25

A4 Countries in the Low- and Middle-Income Class at the Initial Year: Oil Countries Excluded 26

A5 Countries in the Middle-Income Class at the Initial Year: Oil Countries Excluded 27

A6 Countries in the Middle- and High-Income Class at the Initial Year: Oil Countries Excluded 28 


\begin{abstract}
We review the growth experience of middle-income countries. Economic factors associated with growth appear to differ between middle income and other countries. The efficiency of the financial system is importantly related to the growth rate in low- and middle-income countries, but appears to matter less as one moves up the income scale. Demographic variables also matter importantly in low-income countries. In middle-income countries, in contrast, measures of the financial system no longer appear to matter as importantly, as if inefficiencies in banking and financial systems are no longer as binding a constraint as at earlier stages of financial development; nor are demographic variables as important as before. At this point, other variables gain a growing role: these include whether the country experiences a banking or currency crisis, the extent of nonforeign direct investment capital inflows, and government debt as a share of gross domestic product.
\end{abstract}

Keywords: crisis, growth, middle income, total factor productivity

JEL codes: $010,040,047$ 


\section{INTRODUCTION}

Global growth has visibly slowed down since the financial crisis of 2008-2009. Initially, the slowdown was largely confined to the advanced economies where the crisis originated, giving rise to a two-speed world economy of sluggish advanced economies and robust emerging markets. Subsequently, however, growth in emerging markets has also decelerated, further dampening global growth prospects. Slower growth in the advanced economies and the less favorable external environment no doubt played a role in the slower growth of the emerging markets. But a wide range of internal factors may also have contributed to the emerging market slowdown.

In this context, the postcrisis emerging market growth deceleration is giving fresh impetus to the so-called "middle-income trap" debate. The debate is centered on a well-known stylized fact: Many countries made the jump from low income to middle income, but only a handful were able to make the final jump from middle income to high income. A number of structural factors, such as the shift from input-led growth to productivity- and innovation-led growth, make the middle-to-high transition more challenging. The idea of a middle-income trap resonates especially in Asia, which has been transformed by sustained rapid growth from a low-income region to a middle-income region. Of particular interest is the People's Republic of China (PRC), where a tangible decline in the growth rate since the postcrisis period, after decades of world-topping growth that turned the country into the world's second largest economy, is triggering widespread concerns about the middle-income trap. The burning question for the PRC, which is now comfortably middle income, is whether it will follow in the footsteps of Brazil or, more hopefully, in the footsteps of the Republic of Korea.

The literature on the middle-income trap is fundamentally a literature on economic growth in middle-income countries. But much, albeit not all, of that literature leans heavily on anecdotal — that is to say, country- and episode-specific-evidence. (Exceptions include Eichengreen, Park, and Shin 2012; and Pritchett and Summers 2014.) Contributions to that literature consider a limited number of factors or variables. They employ a confusing array of different definitions of what constitutes a middle-income country.

Thus, it is fair to say that this literature and the associated policy debate could both be better informed by empirical facts. In this paper, we seek to impose some structure on this analytical chaos. We adopt the same taxonomy as other studies in this report when defining or identifying middle-income countries. We consider a wide range of factors or definitions designed to encompass the key variables considered in the preceding literature. We look, not only at the significant determinants of the growth of gross domestic product (GDP) per capita, but also at differences in those determinants across the manufacturing and service sectors. And we analyze not just the determinants of the growth of GDP, but also its "growth accounting components," namely capital stock, labor hours, and total factor productivity (TFP).

Our basic findings are that the economic factors associated with per capita income growth do, in fact, differ across countries in different income classes and between middle income and other countries in particular. The critical distinction is between low- and middle-income countries, insofar as we are concerned with how the prospects for growth, and its determinants, change as formerly poor countries experiencing sustained growth graduate to middle-income status. We find that the lendingto-deposit interest rate spread (as a measure of the efficiency of the financial system) is importantly related to the growth rate in low-income countries (in the expected negative direction). The gender ratio (male to female) and working-age population ratio (share of the population that is of working age) are positively associated with growth in low-income countries, confirming the importance of demographics and specifically the demographic dividend (Lee and Mason 2006). 
In contrast, among middle-income countries, the lending-deposit rate spread no longer matters as consistently; this measure of the (under)development of the financial system binds even less frequently and operates less powerfully on growth among high-income countries. Our results suggest, then, that inefficiencies in the financial system matter less, relative to other factors, as countries move up the income scale.

Similarly, the gender ratio is no longer as important as before (although the share of working-age population continues to matter), suggesting the diminishing importance of demographic determinants with graduation to middle-income status. At this point, other variables gain a growing role: these include whether the country experiences a banking or currency crisis (which affects growth negatively), the extent of capital inflows excluding foreign direct investment (FDI) (which affects growth negatively), and government debt as a share of GDP (which again affects growth negatively).

We also distinguish the growth of the manufacturing and service sectors on the grounds that the transition from manufacturing to services is a prominent characteristic, and not infrequently a problem for middle-income countries. There is some sign that demographic factors, government spending, the state of the financial system, and the strength of the political system all matter for the growth of the manufacturing sector in middle-income countries, but the determinants of service sector growth rates are harder to pin down. Put another way, there is a number of concrete policy measures that middleincome countries can do to sustain manufacturing sector growth, but promoting faster service sector growth remains a more elusive quest; it may require, in addition, deep institutional and social reform (Rodrik 2012).

Decomposing overall growth into its proximate growth-accounting components, we find weak evidence that countries that successfully graduate from middle- to high-income status maintain higher investment rates, and strong evidence that they succeed in recording higher TFP growth rates.

We also pursue the point about crises further, given the debate about whether crises affect growth negatively as a result of financial retrenchment (as argued by Reinhart and Rogoff 2009), or positively via their cleansing and reform-galvanizing effect and by encouraging additional investment in the precrisis period (as argued by Tornell and Westermann 2005). We find that very recent crises negatively affect growth, but that past crises do not have a long-run effect on growth either positively or negatively.

An interpretation is that demographic structure and banking sector development are key to growth in low-income countries, but with graduation to middle-income status macroeconomic and financial policies, which shape investment, dependence on portfolio capital inflows, the debt burden, and vulnerability to banking and financial crises, come increasingly to the fore. And when it comes to the movement from middle- to high-income status, the always-elusive determinants of TFP growth emerge as a critical factor.

\section{DATA}

As in other contributions to this project, we define middle-income countries as those with GDP per capita incomes greater than $\$ 2,585$ but less than or equal to $\$ 17,600$ in 2011 purchasing power parity (PPP) terms, according to Penn World Tables 9.0 (PWT 9.0). ${ }^{1}$

1 The cutoff point and definition of middle-income countries were provided by staff of the Asian Development Bank. The latest update of PWT 9.0 is found in Feenstra, Inklaar, and Timmer (2015). 
Middle-income countries can be further classified into (i) lower middle income with GDP per capita incomes that are less than or equal to $\$ 5,351$; and (ii) upper middle income with per capita incomes that are greater than $\$ 5,351$. The income thresholds were derived by making the World Bank income thresholds based on gross national income (GNI) per capita (Atlas method) terms compatible with the PWT data in 2011 PPP. This was done by using the ratios of the average GNI per capita (Atlas method) to GDP per capita in constant PPP per income group (i.e., low income, lower middle income, upper middle income, and high income) and applying them to the thresholds in GNI per capita (Atlas method) to get the equivalent thresholds in GDP per capita in PPP. But some adjustments were effected to make the United States income as the threshold for classifying high-income countries. Further, the thresholds for lower and upper-middleincome countries were calibrated so that there are about the same number of countries in the lower and upper middle-income categories in 1960.

The dependent variable for most of our analysis, the rate of growth of per capita GDP, is collected from PWT 9.0. Given the source, it follows that per capita GDP is expressed in PPP terms. Sources for the other variables are described in Appendix Table A1.

The resulting sample runs from 1960 to 2014 . We divide the sample period into six subsamples: 5 decades (1960-1970, 1971-1980, 1981-1990, 1991-2000, 2001-2010) and a final 4-year period (20112014). We simplify by referring to all subsample periods as "decades" in what follows. Note that, in the following empirical analysis, we use one-period start or period-average observation for each country/decade.

We consider 22 variables that in previous analyses, such as Han and Wei (2015), have been shown to bear some relationship to economic growth:

1. Per capita real GDP growth

2. Years of schooling

3. Investment share

4. Working-age population share

5. Working-age population growth

6. Paved roads (kilometer [km] per number of workers)

7. Electricity-generating capacity (kilowatt per number of workers)

8. Railway ( $\mathrm{km}$ per number of workers)

9. Inflation

10. Domestic credit to private sector (extended by private banks and other financial institutions)

11. Bank credit-to-deposit ratio

12. Lending-to-deposit interest rate spread

13. Banking or currency crisis (number of years with either banking of currency crises divided by 10 for the decade observations and by 4 for the last period [2010-2014])

14. Government debt share (debt-to-GDP ratio)

15. Conflict index

16. Political constraints

17. Accumulated FDI inflows (4 years ahead of each decade)

18. Accumulated non-FDI inflows (4 years ahead of each decade)

19. Trade share (trade [exports + imports] to GDP ratio)

20. Gini index

21. Gender ratio for ages 0-29

22. Government consumption share 
Table 1: Summary Statistics: Oil-Producing Countries Included

\begin{tabular}{|c|c|c|c|c|c|c|c|c|c|c|c|c|c|c|}
\hline \multirow{2}{*}{$\begin{array}{l}\text { Income Level } \\
\text { Variable }\end{array}$} & \multicolumn{2}{|c|}{ (1) All } & \multicolumn{2}{|c|}{ (2) Stays Low } & \multicolumn{2}{|c|}{$\begin{array}{l}\text { (3) Low to } \\
\text { Middle or High }\end{array}$} & \multicolumn{2}{|c|}{$\begin{array}{l}\text { (4) Stays } \\
\text { Middle }\end{array}$} & \multicolumn{2}{|c|}{$\begin{array}{l}\text { (5) Middle to } \\
\text { High }\end{array}$} & \multicolumn{2}{|c|}{ (6) Stays High } & \multicolumn{2}{|c|}{ (7) Drops } \\
\hline & Count & Mean & Count & Mean & Count & Mean & Count & Mean & Count & Mean & Count & Mean & Count & Mean \\
\hline Per capita real GDP growth (\%) & 911 & 1.98 & 241 & 1.16 & 59 & 4.42 & 357 & 2.44 & 61 & 3.71 & 176 & 1.13 & 17 & -1.98 \\
\hline Years of schooling & 726 & 2.30 & 190 & 1.52 & 46 & 2.15 & 279 & 2.45 & 51 & 2.79 & 151 & 2.89 & 9 & 2.49 \\
\hline Investment share & 911 & 0.21 & 241 & 0.14 & 59 & 0.19 & 357 & 0.22 & 61 & 0.28 & 176 & 0.27 & 17 & 0.25 \\
\hline Working-age population share & 875 & 0.59 & 241 & 0.53 & 58 & 0.55 & 343 & 0.59 & 57 & 0.65 & 161 & 0.67 & 15 & 0.58 \\
\hline Working-age population growth (\%) & 875 & 2.04 & 241 & 2.57 & 58 & 2.52 & 343 & 1.93 & 57 & 1.08 & 161 & 1.62 & 15 & 2.28 \\
\hline Paved roads & 452 & -6.21 & 163 & -7.62 & 29 & -6.73 & 169 & -5.84 & 26 & -4.53 & 60 & -3.92 & 5 & -6.11 \\
\hline Electricity-generating capacity & 454 & -8.22 & 165 & -10.11 & 29 & -8.61 & 169 & -7.58 & 26 & -6.18 & 60 & -5.52 & 5 & -8.55 \\
\hline Railway (kilometer) & 418 & -7.66 & 146 & -8.26 & 28 & -7.97 & 161 & -7.56 & 22 & -6.47 & 57 & -6.67 & 4 & -8.20 \\
\hline Inflation & 684 & 0.11 & 150 & 0.11 & 46 & 0.12 & 283 & 0.15 & 49 & 0.06 & 147 & 0.05 & 9 & 0.06 \\
\hline Domestic credit to private sector & 608 & 0.41 & 129 & 0.13 & 39 & 0.18 & 253 & 0.34 & 47 & 0.44 & 130 & 0.88 & 10 & 0.32 \\
\hline Bank credit-to-deposit ratio & 735 & 1.02 & 188 & 1.08 & 47 & 1.03 & 293 & 0.97 & 52 & 0.92 & 145 & 1.09 & 10 & 0.77 \\
\hline Lending-to-deposit interest rate & & & & & & & & & & & & & & \\
\hline spread & 414 & 0.08 & 88 & 0.09 & 28 & 0.12 & 168 & 0.08 & 30 & 0.05 & 95 & 0.04 & 5 & 0.05 \\
\hline Banking or currency crisis & 367 & 0.23 & 47 & 0.24 & 23 & 0.24 & 146 & 0.26 & 28 & 0.18 & 64 & 0.24 & 3 & 0.37 \\
\hline Government debt share & 194 & 0.40 & 2 & 0.15 & 5 & 0.18 & 76 & 0.33 & 26 & 0.37 & 85 & 0.49 & 0 & \\
\hline Conflicts index & 361 & 7.12 & 104 & 7.58 & 23 & 6.92 & 153 & 7.21 & 28 & 6.71 & 47 & 6.26 & 6 & 6.58 \\
\hline Political constraints & 678 & 0.37 & 177 & 0.13 & 46 & 0.25 & 259 & 0.35 & 50 & 0.60 & 137 & 0.66 & 9 & 0.36 \\
\hline Accumulated FDI inflows & 503 & 0.13 & 101 & 0.06 & 32 & 0.16 & 206 & 0.15 & 36 & 0.17 & 120 & 0.14 & 8 & 0.14 \\
\hline Accumulated non-FDI inflows & 462 & 0.21 & 92 & 0.19 & 30 & 0.10 & 187 & 0.14 & 31 & 0.14 & 115 & 0.40 & 7 & 0.19 \\
\hline Trade share & 754 & -0.47 & 190 & -0.79 & 46 & -0.51 & 300 & -0.40 & 55 & -0.34 & 149 & -0.25 & 14 & -0.27 \\
\hline Gini index & 482 & -0.97 & 94 & -0.83 & 34 & -0.84 & 191 & -0.88 & 43 & -1.12 & 113 & -1.23 & 7 & -1.13 \\
\hline Sex ratio & 867 & 1.03 & 237 & 1.00 & 56 & 1.02 & 341 & 1.03 & 57 & 1.04 & 161 & 1.09 & 15 & 1.03 \\
\hline Government consumption share & 911 & 0.20 & 241 & 0.20 & 59 & 0.21 & 357 & 0.20 & 61 & 0.18 & 176 & 0.17 & 17 & 0.27 \\
\hline
\end{tabular}

$\mathrm{FDI}=$ foreign direct investment, GDP = gross domestic product.

Notes: Years of schooling, paved roads, electricity-generating capacity, railway, inflation, conflicts index, trade share in GDP, Gini index are log transformed. Since inflation can take a negative number, we calculate $\ln \left(\pi+\sqrt{\pi^{2}+1}\right.$ ), where $\pi$ is inflation rate. We divide the whole sample into (1) all countries, (2) countries that stayed low-income countries during the decade, (3) countries that moved from low- to a higher (middle- or high-) income countries during the decade, (4) countries that stayed middle-income countries during the decade, (5) countries that moved from middle- to high-income countries during the decade, (6) countries that stayed middle-income countries during the decade, and (7) countries that dropped to lower-income countries during the decade.

Sources: Appendix Table A1 for data sources; and authors' calculation. 
Note that these 22 variables are identical to the 22 variables considered in Han and Wei (2015) with the following exceptions/modifications:

(i) We did not include global growth rate because we add period dummies (fixed effects) in regressions.

(ii) We include the investment share, which was not considered in $\mathrm{Han}$ and Wei.

(iii) We use Gini coefficient instead of the income share of the bottom $40 \%$.

All variables are measured at the initial year except for growth rates that are for the entire decade. We log-transform years of schooling, paved roads, electricity-generating capacity, railway, inflation [= $\left.\ln \left(\pi+\sqrt{\pi^{2}+1}\right)\right]$, conflicts index, trade share of GDP, and the Gini coefficient.

In the sensitivity analysis that follows, we always include (i) initial income, and (ii) years of schooling, and then add any one variable of interest and add n-tuples for sensitivity analysis in the preceding list. For sensitivity analysis of investment share, for example, we always include investment share itself, the initial income and years of education in the regression, and an n-tuple to check the significance of investment share. We chose $n$ equal to 3 following Levine and Renault (1992).

The classification of low-, middle-, and high-income countries follows Han and Wei (2015), taking into consideration the fact that the base years used in their and our study are different (the base year in PWT 9.0 is 2011). Table 1 presents summary statistics (mean and standard deviation) for these variables for the different country groupings distinguished in the analysis: all observations, countries that began a decade as low-income countries and stayed that way; those that moved from low-to middleor high-income status during the decade; those that started a decade as middle income and stayed that way, those that moved from middle- to high-income status in a decade; those that started a decade as high income and stayed that way; and finally countries that dropped to lower-income status in the course of a decade. Note that we report summary statistics when oil countries are included (Table 1) and excluded (Appendix Tables A2-A6). In Table 1, the fuller of the two samples, the number of countries in each of these groupings is relatively similar with the exception of the last (countries that drop to lower-income status in the course of the decade). This suggests treating the results for this last category with caution.

\section{BASIC RESULTS}

In Table 2 through Table 6, we report the regression results (oil-producing countries included) based on the extreme-bounds analysis (EBA) and the entire distribution analysis (EDA) of, inter alia, Sala-iMartin (1997) for various subsamples (i.e., various individual and combinations of income classes). The results, based on the observations excluding oil countries turn out to be very similar and, hence, not reported. An exception is Table 7, for which we report results both with oil-producing countries included and excluded.

Table 2 starts with all country/decade observations. There, as in the tables that follow, RE denotes panel regressions with random effects, FE panel regressions with fixed effects, and GMM generalized-method-of-moments estimates of dynamic panel regressions. The base Beta is the estimated coefficient of the variable of interest from the regression with the variable and the alwaysincluded variables (initial income and years of schooling). The high Beta is then the estimated coefficient of the variable of interest from the regression with the extreme high bound, while the low Beta is the 
estimated coefficient of the variable of interest from the regression with the extreme low bound. "Other Variables" refer to the additional variables included beside the variable of interest and the alwaysincluded variables when producing the extreme bound coefficients.

Table 2: All Country and Decade Observation

(a) Extreme-bounds analysis

\begin{tabular}{|c|c|c|c|c|c|c|c|c|c|c|}
\hline & Variable & & eta & SE & $\mathrm{t}$-stat & Obs & Groups & $\mathrm{R}^{2}$ & $\begin{array}{c}\text { Other } \\
\text { Variables }\end{array}$ & NS \\
\hline \multirow{12}{*}{ RE } & \multirow{3}{*}{$\begin{array}{l}\text { Investment } \\
\text { share }\end{array}$} & high & 0.122 & {$[0.036]$} & 3.43 & 96 & 50 & 0.34 & v11 v13 v15 & \multirow{3}{*}{73} \\
\hline & & base & 0.043 & {$[0.017]$} & 2.54 & 726 & 138 & 0.20 & - & \\
\hline & & low & 0.007 & {$[0.028]$} & 0.24 & 129 & 80 & 0.45 & v2 v10 v13 & \\
\hline & \multirow{3}{*}{ Work ratio } & high & 0.41 & {$[0.067]$} & 6.09 & 234 & 86 & 0.41 & v3 v4 v15 & \multirow{3}{*}{0} \\
\hline & & base & 0.166 & {$[0.026]$} & 6.27 & 720 & 137 & 0.25 & - & \\
\hline & & low & 0.070 & [0.044] & 1.61 & 136 & 36 & 0.46 & v11 v12 v18 & \\
\hline & \multirow{3}{*}{$\begin{array}{l}\text { Banking or } \\
\text { currency crisis }\end{array}$} & high & -0.006 & {$[0.007]$} & -0.94 & 95 & 50 & 0.49 & v2 v13 v16 & \multirow{3}{*}{1} \\
\hline & & base & -0.018 & [0.004] & -4.34 & 304 & 66 & 0.20 & - & \\
\hline & & low & -0.029 & {$[0.006]$} & -4.73 & 67 & 43 & 0.29 & v9 v10 v13 & \\
\hline & \multirow{3}{*}{$\begin{array}{l}\text { Accumulated } \\
\text { non-FDI } \\
\text { inflows }\end{array}$} & high & -0.001 & {$[0.006]$} & -0.17 & 71 & 32 & 0.55 & v2 v12 v13 & \multirow{3}{*}{34} \\
\hline & & base & -0.01 & [0.003] & -3.15 & 400 & 127 & 0.23 & - & \\
\hline & & low & -0.035 & [0.009] & -3.95 & 110 & 62 & 0.25 & v5 v8 v13 & \\
\hline \multirow{6}{*}{ FE } & \multirow{3}{*}{$\begin{array}{l}\text { Banking or } \\
\text { currency crisis }\end{array}$} & high & -0.006 & {$[0.005]$} & -1.30 & 164 & 62 & 0.45 & v2 v3 v16 & \multirow{3}{*}{0} \\
\hline & & base & -0.017 & [0.004] & -4.41 & 304 & 66 & 0.37 & - & \\
\hline & & low & -0.026 & [0.007] & -3.91 & 70 & 44 & 0.74 & v2 v10 v13 & \\
\hline & \multirow{3}{*}{$\begin{array}{l}\text { Accumulated } \\
\text { non-FDI } \\
\text { inflows }\end{array}$} & high & 0.014 & {$[0.011]$} & 1.22 & 66 & 41 & 0.78 & v10 v11 v13 & \multirow{3}{*}{70} \\
\hline & & base & -0.012 & {$[0.005]$} & -2.60 & 400 & 127 & 0.36 & - & \\
\hline & & low & -0.048 & {$[0.016]$} & -3.09 & 176 & 90 & 0.45 & v3 v13 & \\
\hline \multirow{6}{*}{ GMM } & \multirow{3}{*}{$\begin{array}{l}\text { Banking or } \\
\text { currency crisis }\end{array}$} & high & -0.046 & [0.152] & -0.30 & 92 & 34 & & v2 v12 v16 & \multirow{3}{*}{14} \\
\hline & & base & -0.271 & [0.051] & -5.27 & 304 & 66 & & - & \\
\hline & & low & -0.527 & [0.183] & -2.88 & 96 & 50 & & v3 v13 v15 & \\
\hline & \multirow{3}{*}{$\begin{array}{l}\text { Accumulated } \\
\text { non-FDI } \\
\text { inflows }\end{array}$} & high & 0.169 & {$[0.099]$} & 1.71 & 89 & 33 & & $\mathrm{v} 1 \mathrm{v} 5 \mathrm{v} 12$ & \multirow{3}{*}{98} \\
\hline & & base & -0.09 & [0.016] & -5.75 & 401 & 127 & & - & \\
\hline & & low & -0.803 & {$[0.400]$} & -2.01 & 95 & 50 & & v3 v11 v13 & \\
\hline
\end{tabular}

$\mathrm{FDI}=$ foreign direct investment, $\mathrm{GDP}=$ gross domestic product, $\mathrm{SE}=$ standard error, $\mathrm{v} 1$ = investment share, $\mathrm{v} 2$ = working-age population share, $\mathrm{v} 3$ = working-age population growth, $\mathrm{v} 4=$ paved roads (kilometer $[\mathrm{km}]$ per number of workers), $\mathrm{v}$ = electricity-generating capacity (kilowatt per number of workers), $v 8=$ domestic credit to private sector (extended by private banks and other financial institutions), $v 9=$ bank credit-todeposit ratio, v10 = lending-to-deposit interest rate spread, v11 = banking or currency crisis (number of years with either banking of currency crises divided by 10 for the decade observations and by 4 for the last period [2010-2014]), v12 = government debt share (debt-to-GDP ratio), $\mathrm{v} 13=$ conflict index, $\mathrm{v} 15$ = accumulated FDI inflows (4 years ahead of each decade), v16 = accumulated non-FDI inflows ( 4 years ahead of each decade), $v 18=$ Gini index.

Notes: All country/decade observations are used for estimation. RE refers to panel regression with random effects, FE refers to panel regression with fixed effects, and GMM refers to generalized method of moments approach to dynamic panel regression. The base Beta reports the estimated coefficient of variable from the regression with the variable and the always-included variables (initial income and years of schooling) used as regressors. The high Beta reports the extreme high bound of the estimated coefficient of variable of interest; the low Beta reports the extreme low bound of variable of interest. Other variables are the variables that are included besides the variable of interest and the alwaysincluded variables, in producing the extreme bound coefficient. We report variables if they are insignificant at the 5\% level (one sided) less than $10 \%$ of all the sensitivity regressions. NS is the number of regressions where the estimated coefficient is not significant at the $5 \%$ level (one sided). Source: Authors' calculation. 


\section{(b) Entire distribution analysis}

\begin{tabular}{llrrrcc}
\hline \multicolumn{1}{c}{ Variable } & Beta & df & SD & $\begin{array}{c}\text { Mean of } \\
\text { P-Value }\end{array}$ & $\begin{array}{c}\text { P-Value of } \\
\text { the Mean }\end{array}$ \\
\hline \multirow{4}{*}{ RE } & Investment share & 0.052 & 285.510 & 0.023 & 0.027 & 0.013 \\
& Work ratio & 0.212 & 285.436 & 0.043 & 0.001 & 0.000 \\
& Banking or currency crisis & -0.018 & 176.734 & 0.005 & 0.001 & 0.000 \\
& Government debt share & -0.010 & 115.548 & 0.006 & 0.112 & 0.042 \\
& Accumulated non-FDI inflows & -0.010 & 204.079 & 0.005 & 0.017 & 0.016 \\
\hline \multirow{2}{*}{ FE } & Work ratio & 0.150 & 85.714 & 0.063 & 0.055 & 0.010 \\
& Banking or currency crisis & -0.016 & 54.968 & 0.005 & 0.003 & 0.001 \\
& Accumulated non-FDI inflows & -0.011 & 80.943 & 0.005 & 0.028 & 0.027 \\
\hline \multirow{2}{*}{ GMM } & Banking or currency crisis & -0.270 & 176.734 & 0.077 & 0.005 & 0.096 \\
& Accumulated non-FDI inflows & -0.170 & 204.278 & 0.085 & 0.032 & 0.023 \\
\hline
\end{tabular}

$\mathrm{FDI}=$ foreign direct investment, $\mathrm{FE}=$ panel regression with fixed effects, $\mathrm{GMM}=$ generalized method of moments, $\mathrm{RE}=$ panel regression with random effects.

Notes: Beta, df, and SD are weighted averages of the estimated coefficients, degrees of freedom, and standard deviations, respectively, using the likelihood values as weights in the sensitivity regressions for each variable reported in Table $2 a$. Mean of $p$-value is weighted average of $p$ values; $p$ value of the mean is $p$-value of the average coefficient using the average standard errors that are calculated from the weighted average of estimated variances. We report variables only when the mean of $p$-value or $p$-value of the mean is less than .05 . Sources: Appendix Table A1 for data sources; and authors' calculation.

EBA sometimes imposes the restriction that the relevant coefficients must be statistically significant in every single regression on which the sensitivity analyses are based. In practice, few of our variables satisfy this relatively strict criterion. We, therefore, relaxed the restriction to enable us to report coefficients for a variable if its coefficient is insignificant in less than $10 \%$ of all the sensitivity regressions. In other words, when we do $1,159\left(=_{19} C_{3}+{ }_{19} C_{2}+{ }_{19} C_{1}\right)$ sensitivity regressions, we report results for a variable if at most 115 cases yield a coefficient that is insignificantly different from zero at the $5 \%$ level (one-sided test). In the above equation, 19 is calculated by subtracting 3 (two always-included variable and the variable of interest) from 22 variables listed above.

In the case of EDA, we report coefficients for a variable when the average $p$-value (weighted by likelihood) or p-value of the average of coefficients (using average standard errors) is less than 0.05.

The results differ a bit, depending on whether random effects, fixed effects, or GMM are used. The EBA points to the importance of banking and currency crises (which depress growth) and accumulated non-FDI (portfolio and "other," in practice mainly bank related) financial capital inflows. In addition, the random effects results suggest a role for the investment share and the share of the population that is of working age. Magnitudes vary; one magnitude to worry about is that on non-FDI inflows, the coefficient of which can switch from positive to negative, depending on whether the high or low value is used.

The EDA results again point to the importance of banking and currency crises as well as accumulated non-FDI inflows. In addition, the random-effects and fixed-effects results suggest a role for the investment share and working-age-population share, as before, and also now to the ratio of government debt to GDP (which enters negatively according to the random-effects results).

Table 3 focuses on all country/decade observations for which the corresponding country belongs to the group of low-income countries in the initial year of the decade. (Note that we, therefore, also include country/decade observations for which the country starts the decade as low income, but ends it as middle or high income.) Here, the EBA results point to the importance of the lending-todeposit interest rate spread (a measure of the efficiency of the banking system) and the gender ratio, 
where the spread has a clear negative impact on growth, while the gender ratio has a positive base effect, but we cannot rule out the possibility of a negative coefficient. The EDA results similarly single out the spread (again with its negative effect) and the gender ratio (again with a positive effect), and in addition point to the positive effect of a relatively large share of the population that is of working age.

Table 3: Countries in the Low-Income Class at the Initial Year

(a) Extreme-bounds analysis

\begin{tabular}{|c|c|c|c|c|c|c|c|c|c|c|}
\hline & Variable & & Beta & SE & t-stat & Obs & Groups & $R^{2}$ & $\begin{array}{c}\text { Other } \\
\text { Variables }\end{array}$ & NS \\
\hline \multirow{6}{*}{ RE } & \multirow{4}{*}{$\begin{array}{l}\text { Lending-to- } \\
\text { deposit } \\
\text { interest rate } \\
\text { spread }\end{array}$} & high & -0.025 & [0.098] & -0.26 & 43 & 25 & 0.62 & v1 v8 v16 & \multirow{4}{*}{62} \\
\hline & & base & -0.144 & {$[0.068]$} & -2.11 & 72 & 31 & 0.42 & & \\
\hline & & low & -0.514 & [0.171] & -3.00 & 34 & 20 & 0.68 & v9 v16 v18 & \\
\hline & & high & 0.640 & [0.239] & 2.68 & 24 & 11 & 0.51 & v11 v17 v18 & \\
\hline & \multirow[t]{2}{*}{ Sex ratio } & base & 0.140 & [0.053] & 2.63 & 195 & 53 & 0.26 & & \multirow[t]{2}{*}{114} \\
\hline & & low & -0.381 & [0.219] & -1.74 & 43 & 19 & 0.52 & v2 v6 v11 & \\
\hline
\end{tabular}

$\mathrm{FDI}=$ foreign direct investment, $\mathrm{GDP}=$ gross domestic product, $\mathrm{RE}=$ panel regression with random effects, $\mathrm{SE}=$ standard error, $\mathrm{v} 1=$ investment share, $\mathrm{v} 2$ = working-age population share, $\mathrm{v} 6=$ railway $(\mathrm{km}$ per number of workers), $\mathrm{v} 8=$ domestic credit to private sector (extended by private banks and other financial institutions), $\mathrm{v} 9$ = bank credit-to-deposit ratio, $\mathrm{v} 11$ = banking or currency crisis (number of years with either banking of currency crises divided by 10 for the decade observations and by 4 for the last period [2010-2014]), $\mathrm{v} 16=$ accumulated non-FDI inflows (4 years ahead of each decade), $\mathrm{v} 17$ = trade share (trade [exports + imports] to GDP ratio), v18 $=$ Gini index .

Notes: Extreme-bounds analysis is done by using observations for which the corresponding country belongs to low-income countries at the initial year of the decade. All country/decade observations are used for estimation. The base Beta reports the estimated coefficient of variable from the regression with the variable and the always-included variables (initial income and years of schooling) used as regressors. The high Beta reports the extreme high bound of the estimated coefficient of variable of interest; the low Beta reports the extreme low bound of variable of interest. Other variables are the variables that are included besides the variable of interest and the always-included variables, in producing the extreme bound coefficient. We report variables if they are insignificant at the $5 \%$ level (one sided) less than $10 \%$ of all the sensitivity regressions. NS is the number of regressions where the estimated coefficient is not significant at the $5 \%$ level (one sided).

Source: Authors' calculation.

(b) Entire distribution analysis

\begin{tabular}{|c|c|c|c|c|c|c|}
\hline & Variable & Beta & $\mathrm{df}$ & SD & $\begin{array}{l}\text { Mean of } \\
\text { P-Value }\end{array}$ & $\begin{array}{l}\mathrm{P}-\mathrm{V} \text { alue of } \\
\text { the Mean }\end{array}$ \\
\hline \multirow{3}{*}{ RE } & Work ratio & 0.271 & 59.582 & 0.121 & 0.064 & 0.015 \\
\hline & Lending-to-deposit interest rate spread & -0.210 & 30.683 & 0.096 & 0.036 & 0.018 \\
\hline & Sex ratio & 0.258 & 59.827 & 0.112 & 0.040 & 0.013 \\
\hline
\end{tabular}

$\mathrm{RE}=$ panel regression with random effects.

Notes: Entire distribution analysis is done by using observations for which the corresponding country belongs to low-income countries at the initial year of the decade. Beta, df, and SD are weighted averages of the estimated coefficients, degrees of freedom, and standard deviations, respectively, using the likelihood values as weights in the sensitivity regressions for each variable reported in Table $2 a$. Mean of $p$-value is weighted average of $p$ values; $p$ value of the mean is $p$-value of the average coefficient using the average standard errors that are calculated from the weighted average of estimated variances. We report variables only when the mean of $p$-value or $p$-value of the mean is less than .05 .

Source: Authors' calculation.

The role of the share of the population that is of working age has been emphasized in the literature on the demographic dividend, as noted above. The role of the gender ratio in low- and middleincome countries, while the subject of less attention, has been analyzed by Han and Wei (2015). 


\begin{abstract}
"Wei and Zhang (2011a, 2011b, and 2012) and Du and Wei (2013) suggested marriage market competition as a key motivation for savings, labor supply, and work effort-a higher level of wealth relative to one's competitor in the dating/marriage market gives one an edge in attracting the opposite sex. This is true regardless of the sex ratio. But in cases of a higher male/female ratio in the pre-marital age cohort, a certain fraction of males will not be able to find a girlfriend or wife. The drive to create and accumulate physical wealth becomes stronger. This implies that a higher sex ratio (or, more precisely, deviations from a balanced sex ratio in either direction) tends to be associated with a higher rate of economic growth."
\end{abstract}

Our results are not inconsistent with their conjectures.

Table 4 includes all country/decade observations for which the corresponding country belongs to either low- or middle-income country groupings in the initial year of the decade. (Again, we did not impose any restriction on the final year of the decade). Here, the share of the working-age population continues to matter, while there is also a role for banking and currency crises according to the EDA. Table 5 next does the same for all country/decade observations for which the corresponding country belongs to the group of middle-income countries in the initial year of the decade; the results are entirely consistent with those in Table 4. Finally, Table 6 repeats the exercise for the combined groups of middleand high-income countries. In this case, there appears to be a role for banking and currency crises, as before, perhaps for the share of the population that is of working age (although this variable registers now in only about half of the cases considered), and accumulated non-FDI-related capital inflows. It makes sense that portfolio capital inflows show up as mattering more for middle- and high-income countries than they do for the low-income grouping, since until recently many low-income countries had maintained relatively strict capital controls and, for other reasons such as political instability and financial underdevelopment, were not on the receiving end of large non-FDI-related flows.

Table 4: Countries in the Low- and Middle-Income Class at the Initial Year

(a) Extreme-bounds analysis

\begin{tabular}{cccccccccc}
\hline & & & & & & & & & Other \\
Variable & \multicolumn{2}{c}{ Beta } & SE & t-stat & Obs & Groups & $\mathrm{R}^{2}$ & Variables & NS \\
\hline \multirow{3}{*}{ RE } & high & 0.492 & {$[0.070]$} & 7.02 & 131 & 71 & 0.50 & v3v13v15 \\
& Work ratio & base & 0.143 & {$[0.031]$} & 4.59 & 522 & 120 & 0.23 & 29 \\
& & low & -0.055 & {$[0.163]$} & -0.34 & 40 & 18 & 0.20 & v9 v12 v15 \\
\hline
\end{tabular}

$\mathrm{RE}=$ panel regression with random effects.

v3 = working-age population growth, v9 = bank credit-to-deposit ratio, v12 = government debt share (debt-to-GDP ratio), v13 = conflict index, v15 = accumulated FDI inflows (4 years ahead of each decade).

Notes: Extreme-bounds analysis is done by using observations for which the corresponding country belongs to either low- or middleincome countries at the initial year of the decade. All country/decade observations are used for estimation. The base Beta reports the estimated coefficient of variable from the regression with the variable and the always-included variables (initial income and years of schooling) used as regressors. The high Beta reports the extreme high bound of the estimated coefficient of variable of interest; the low Beta reports the extreme low bound of variable of interest. Other variables are the variables that are included besides the variable of interest and the always-included variables, in producing the extreme bound coefficient. We report variables if they are insignificant at the $5 \%$ level (one sided) less than $10 \%$ of all the sensitivity regressions. NS is the number of regressions where the estimated coefficient is not significant at the $5 \%$ level (one sided).

Source: Authors' calculation. 


\section{(b) Entire distribution analysis}

\begin{tabular}{clccccc}
\hline & \multicolumn{1}{c}{ Variable } & Beta & df & SD & $\begin{array}{c}\text { Mean of } \\
\text { P-Value }\end{array}$ & $\begin{array}{c}\text { P-Value of } \\
\text { the Mean }\end{array}$ \\
\hline \multirow{2}{*}{$\mathrm{RE}$} & Work ratio & 0.224 & 193.357 & 0.064 & 0.011 & 0.000 \\
& Banking or currency crisis & -0.017 & 111.185 & 0.009 & 0.044 & 0.029 \\
\hline $\mathrm{FE}$ & Banking or currency crisis & -0.016 & 43.022 & 0.009 & 0.102 & 0.043 \\
\hline
\end{tabular}

$\mathrm{FE}=$ panel regression with fixed effects, $\mathrm{RE}=$ panel regression with random effects.

Notes: Entire distribution analysis is done by using observations for which the corresponding country belongs to either low- or middleincome countries at the initial year of the decade. Beta, df, and SD are weighted averages of the estimated coefficients, degrees of freedom, and standard deviations, respectively, using the likelihood values as weights in the sensitivity regressions for each variable reported in Table 2a. Mean of $p$-value is weighted average of $p$ values; $p$ value of the mean is $p$-value of the average coefficient using the average standard errors that are calculated from the weighted average of estimated variances. We report variables only when the mean of p-value or p-value of the mean is less than .05 .

Source: Authors' calculation.

\section{Table 5: Countries in the Middle-Income Class at the Initial Year}

\section{(a) Extreme-bounds analysis}

\begin{tabular}{|c|c|c|c|c|c|c|c|c|c|c|}
\hline & Variable & & & SE & t-stat & Obs & Groups & $\mathrm{R}^{2}$ & $\begin{array}{c}\text { Other } \\
\text { Variables }\end{array}$ & NS \\
\hline \multirow{3}{*}{ RE } & \multirow{3}{*}{$\begin{array}{l}\text { Work } \\
\text { ratio }\end{array}$} & high & 0.518 & {$[0.076]$} & 6.79 & 91 & 52 & 0.54 & v3 v13 v15 & \multirow{3}{*}{29} \\
\hline & & base & 0.208 & [0.032] & 6.43 & 326 & 103 & 0.38 & & \\
\hline & & low & -0.055 & [0.163] & -0.34 & 40 & 18 & 0.20 & v9 v12 v15 & \\
\hline
\end{tabular}

$\mathrm{FDI}=$ foreign direct investment, $\mathrm{GDP}=$ gross domestic product, $\mathrm{RE}=$ panel regression with fixed effect, $\mathrm{SE}=$ standard error, $\mathrm{v} 3=$ working-age population growth, $\mathrm{v} 9=$ bank credit-to-deposit ratio, $\mathrm{v} 12=$ government debt share (debt-to-GDP ratio), v13 = conflict index, 115 = accumulated FDI inflows (4 years ahead of each decade).

Notes: Extreme-bounds analysis is done by using observations for which the corresponding country belongs to middle-income countries at the initial year of the decade. All country/decade observations are used for estimation. The base Beta reports the estimated coefficient of variable from the regression with the variable and the always-included variables (initial income and years of schooling) used as regressors. The high Beta reports the extreme high bound of the estimated coefficient of variable of interest; the low Beta reports the extreme low bound of variable of interest. Other variables are the variables that are included besides the variable of interest and the always-included variables, in producing the extreme bound coefficient. We report variables if they are insignificant at the 5\% level (one sided) less than $10 \%$ of all the sensitivity regressions. NS is the number of regressions where the estimated coefficient is not significant at the $5 \%$ level (one sided).

Source: Authors' calculation.

\section{(b) Entire distribution analysis}

\begin{tabular}{|c|c|c|c|c|c|c|}
\hline & Variable & Beta & df & SD & $\begin{array}{l}\text { Mean of } \\
\text { P-Value }\end{array}$ & $\begin{array}{l}\text { P-Value of } \\
\text { the Mean }\end{array}$ \\
\hline \multirow{2}{*}{ RE } & Work ratio & 0.253 & 131.432 & 0.063 & 0.009 & 0.000 \\
\hline & Banking or currency crisis & -0.017 & 91.450 & 0.010 & 0.084 & 0.041 \\
\hline FE & Banking or currency crisis & -0.018 & 41.193 & 0.010 & 0.115 & 0.036 \\
\hline
\end{tabular}

$\mathrm{FE}=$ panel regression with fixed effects, $\mathrm{RE}=$ panel regression with random effects.

Notes: Entire distribution analysis is done by using observations for which the corresponding country belongs to middle-income countries at the initial year of the decade. Beta, $\mathrm{df}$, and SD are weighted averages of the estimated coefficients, degrees of freedom, and standard deviations, respectively, using the likelihood values as weights in the sensitivity regressions for each variable reported in Table $2 a$. Mean of $p$-value is weighted average of $p$ values; $p$ value of the mean is $p$-value of the average coefficient using the average standard errors that are calculated from the weighted average of estimated variances. We report variables only when the mean of $p$-value or $p$ value of the mean is less than 05 .

Source: Authors' calculation.

In one case (the entire distribution analysis where equations include random effects), there also appears to be an influence of the investment share of GDP. Recall that this variable showed up in the random effects estimates for the entire sample (Table 2). Table 6 is telling us that this effect is largely limited to - that it matters most—for middle- and high-income countries. 
Table 7 summarizes Tables 2-6, along with appendix tables, based on observations excluding oil countries) to report variables that pass the EBA and EDA. It turns out that the results, including and excluding oil exporters, are broadly similar, so we discuss results including oil-producing countries. Clearly, the factors associated with growth differ when countries are grouped by per capita income or level of economic development. The critical distinction is between low- and middle-income countries, insofar as we are concerned with how the prospects for growth, and its determinants, change as formerly poor countries experiencing sustained growth graduate to middle-income status. The lending-todeposit interest rate spread (as a measure of the efficiency of the financial system) is importantly related to the growth rate in low-income countries (in the expected negative direction). The gender ratio (male to female) and working-age population ratio (share of the population that is of working age) are both positively associated with growth, confirming that demographics and specifically, the demographic dividend matter importantly for low-income countries (think India, for example).

\section{Table 6: Countries in the Middle- and High-Income Class at the Initial Year}

\section{(a) Extreme-bounds analysis}

\begin{tabular}{|c|c|c|c|c|c|c|c|c|c|c|}
\hline & & & & & & & & & Other & \\
\hline & Variable & & eta & SE & t-stat & Obs & Groups & $\mathrm{R}^{2}$ & Variables & NS \\
\hline & & high & 0.395 & {$[0.076]$} & 5.22 & 46 & 25 & 0.62 & v10 v12 v13 & \\
\hline & Work ratio & base & 0.214 & {$[0.027]$} & 7.92 & 524 & 120 & 0.39 & & 0 \\
\hline & & low & 0.070 & {$[0.044]$} & 1.61 & 136 & 36 & 0.46 & v11 v12 v18 & \\
\hline & & high & -0.006 & {$[0.005]$} & -1.11 & 143 & 57 & 0.40 & v2 v4 v16 & \\
\hline $\mathrm{RE}$ & Banking or & base & -0.019 & {$[0.004]$} & -4.31 & 256 & 64 & 0.28 & & 1 \\
\hline & & low & -0.028 & {$[0.006]$} & -4.58 & 42 & 24 & 0.26 & v10 v12 v13 & \\
\hline & Accumulated & high & -0.001 & [0.007] & -0.11 & 87 & 47 & 0.51 & v2 v11 v13 & \\
\hline & non-FDI & base & -0.008 & {$[0.003]$} & -2.69 & 323 & 110 & 0.26 & & 78 \\
\hline & inflows & low & -0.035 & {$[0.010]$} & -3.55 & 91 & 49 & 0.30 & v5v9 v13 & \\
\hline & & high & -0.005 & {$[0.005]$} & -0.95 & 149 & 60 & 0.46 & v2 v3 v16 & \\
\hline & Banking or & base & -0.018 & {$[0.004]$} & -4.50 & 256 & 64 & 0.51 & & 2 \\
\hline & & low & -0.026 & {$[0.005]$} & -4.90 & 42 & 24 & 0.8 & v10 v12 v13 & \\
\hline rt & Accumulated & high & 0.014 & {$[0.011]$} & 1.21 & 62 & 37 & 0.78 & v10 v11 v13 & \\
\hline & non-FDI & base & -0.011 & {$[0.005]$} & -2.40 & 323 & 110 & 0.33 & & 56 \\
\hline & inflows & low & -0.057 & {$[0.016]$} & -3.47 & 134 & 69 & 0.55 & v3 v13 v17 & \\
\hline & & high & -0.052 & [0.080] & -0.65 & 127 & 53 & & v2 v8 v16 & \\
\hline & Banking or & base & -0.264 & [0.055] & -4.79 & 235 & 60 & & & 5 \\
\hline GMMM & & low & -0.404 & [0.095] & -4.24 & 55 & 36 & & v8 v10 v13 & \\
\hline GTININ & Accumulated & high & 0.091 & [0.151] & 0.60 & 59 & 36 & & v10 v11 v13 & \\
\hline & non-FDI & base & -0.064 & {$[0.021]$} & -3.12 & 300 & 103 & & & 100 \\
\hline & inflows & low & -0.581 & {$[0.204]$} & -2.84 & 88 & 47 & & v5 v13 v20 & \\
\hline
\end{tabular}

$\mathrm{FDI}=$ foreign direct investment, $\mathrm{GDP}=$ gross domestic product, $\mathrm{v2}$ = working-age population share, $\mathrm{v} 3$ = working-age population growth, $\mathrm{v} 4$ = paved roads (kilometer [km] per number of workers), v5 = electricity-generating capacity (kilowatt per number of workers), v8 = domestic credit to private sector (extended by private banks and other financial institutions), $\mathrm{v} 9=$ bank credit-to-deposit ratio, $\mathrm{v} 10=$ lending-to-deposit interest rate spread, $\mathrm{v} 11$ = banking or currency crisis (number of years with either banking of currency crises divided by 10 for the decade observations and by 4 for the last period [2010-2014]), v12 = government debt share (debt-to-GDP ratio), v13 = conflict index, v16 = accumulated non-FDI inflows (4 years ahead of each decade), v17 = trade share (trade [exports + imports] to GDP ratio), v18 = Gini index, v20 = government consumption share.

Notes: Extreme-bounds analysis is done by using observations for which the corresponding country belongs to middle- or high-income countries at the initial year of the decade. All country/decade observations are used for estimation. RE refers to panel regression with random effects, FE refers to panel regression with fixed effects, and GMM refers to generalized method of moments approach to dynamic panel regression. The base Beta reports the estimated coefficient of variable from the regression with the variable and the always-included variables (initial income and years of schooling) used as regressors. The high Beta reports the extreme high bound of the estimated coefficient of variable of interest; the low Beta reports the extreme low bound of variable of interest. Other variables are the variables that are included besides the variable of interest and the always-included variables, in producing the extreme bound coefficient. We report variables if they are insignificant at the $5 \%$ level (one sided) less than $10 \%$ of all the sensitivity regressions. NS is the number of regressions where the estimated coefficient is not significant at the $5 \%$ level (one sided).

Source: Authors' calculation. 
(b) Entire distribution analysis

\begin{tabular}{llccccc}
\hline & \multicolumn{1}{c}{ Variable } & Beta & df & SD & $\begin{array}{c}\text { Mean of } \\
\text { P-Value }\end{array}$ & $\begin{array}{c}\text { P-Value of } \\
\text { the Mean }\end{array}$ \\
\hline \multirow{4}{*}{ RE } & Investment share & 0.045 & 223.585 & 0.022 & 0.050 & 0.022 \\
& Work ratio & 0.226 & 223.511 & 0.043 & 0.001 & 0.000 \\
& Banking or currency crisis & -0.017 & 157.000 & 0.005 & 0.003 & 0.000 \\
& Government debt share & -0.010 & 114.795 & 0.006 & 0.107 & 0.038 \\
& Accumulated non-FDI inflows & -0.008 & 165.669 & 0.004 & 0.024 & 0.029 \\
\hline \multirow{2}{*}{$F E$} & Work ratio & 0.153 & 72.842 & 0.065 & 0.931 & 0.011 \\
& Banking or currency crisis & -0.016 & 53.139 & 0.005 & 0.005 & 0.001 \\
& Accumulated non-FDI inflows & -0.011 & 68.539 & 0.005 & 0.029 & 0.022 \\
\hline \multirow{2}{*}{ GMM } & Banking or currency crisis & -0.223 & 144.570 & 0.073 & 0.006 & 0.001 \\
& Accumulated non-FDI inflows & -0.144 & 153.844 & 0.078 & 0.027 & 0.034 \\
\hline
\end{tabular}

$\mathrm{FDI}=$ foreign direct investment, $\mathrm{FE}=$ panel regression with fixed effects, $\mathrm{GMM}=$ generalized method of moments, $\mathrm{RE}=$ panel regression with random effects.

Notes: Entire distribution analysis is done by using observations for which the corresponding country belongs to middle- or high-income countries at the initial year of the decade. Beta, df, and SD are weighted averages of the estimated coefficients, degrees of freedom, and standard deviations, respectively, using the likelihood values as weights in the sensitivity regressions for each variable reported in Table 2a. Mean of $p$-value is weighted average of $p$ values; $p$ value of the mean is $p$-value of the average coefficient using the average standard errors that are calculated from the weighted average of estimated variances. We report variables only when the mean of $\mathrm{p}$-value or $\mathrm{p}$-value of the mean is less than 05 .

Source: Authors' calculation.

Among middle-income countries, in contrast, the lending-to-deposit interest rate spread no longer matters as important, as if inefficiencies in the banking and financial system are no longer as binding a constraint as at earlier stages of economic development. This variable is even less consistently related to growth among high- than middle-income countries. (When we include oil exporters, random effects estimates, including the lending-to-deposit interest rate spread, yield negative coefficients in 703 cases and no single case of a positive coefficient. Fixed-effects estimates produce 632 negative coefficients and only 71 positive coefficients, GMM estimates 689 versus 14 . We obtain a larger number of positive coefficients for middle-income countries and a still larger number for high-income countries. Regressions substituting private credit relative to GDP as a measure of financial development yield precisely the same pattern, albeit with the opposite sign, consistent with the above. In this case, though, we find relatively more supporting evidence that financial development is important for middle-income countries in the sense that, in some estimations, the number of positive coefficients for middle-income countries is larger than that for low-income countries as well as than that for high-income countries.) Our results, thus, suggest that inefficiencies in the financial system matter less, relative to other factors, as countries move up the income scale.

Similarly, the gender ratio is no longer as important as before, indicating the declining role of demographic determinants with graduation to middle-income status. At this point, other variables gain a growing role: these include whether the country experiences a banking or currency crisis (which affects growth negatively), extent of non-FDI capital inflows (which affects growth negatively), and government debt as a share of GDP (which again affects growth negatively).

Finally, among high-income countries, there is a positive association between investment and growth in a few (but not all) of our estimates. 
Table 7: Economic Factors that are Associated with Growth for Different Income Classes

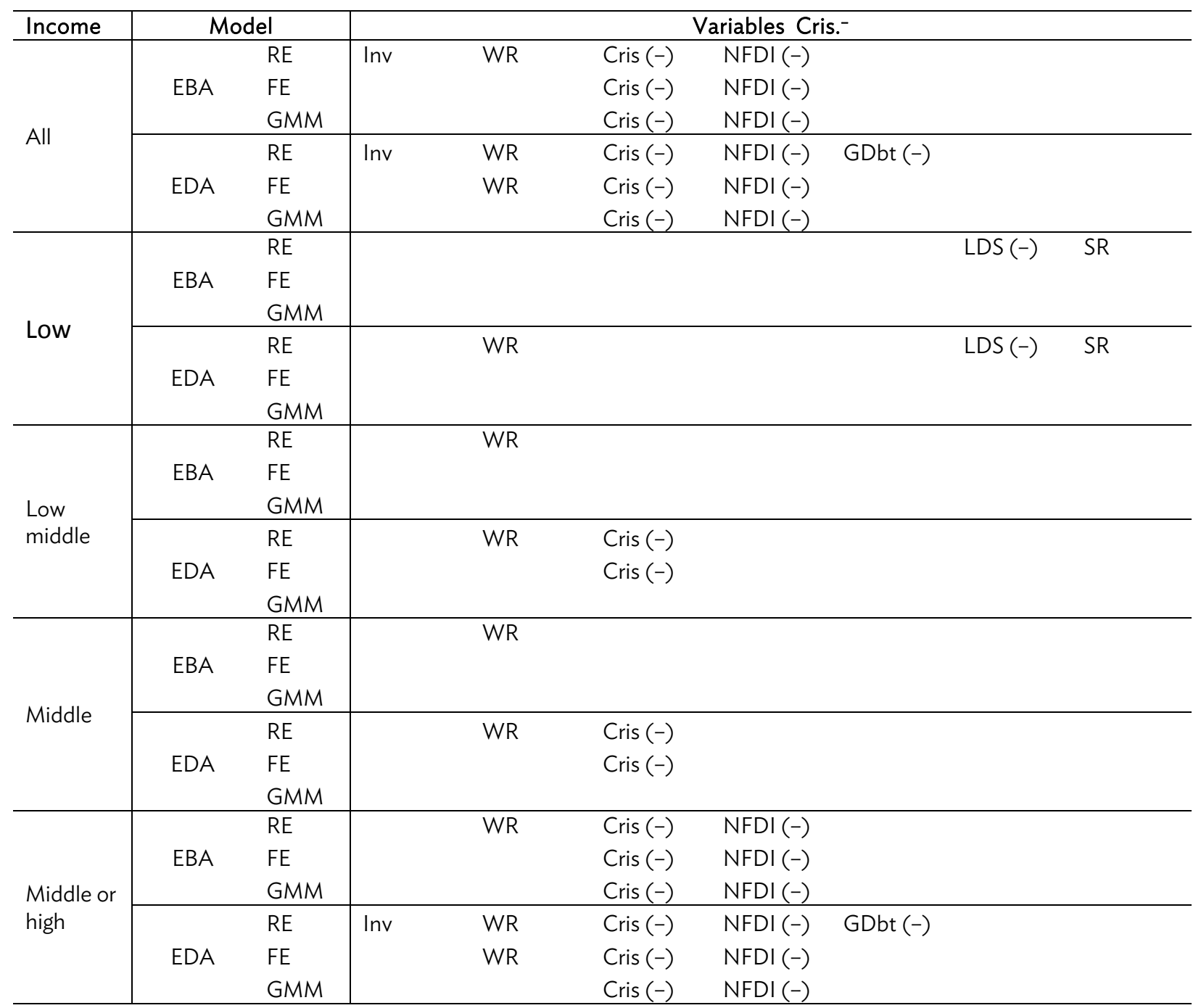

$\mathrm{EBA}=$ extreme-bounds analysis, $\mathrm{EDA}=$ entire distribution analysis, $\mathrm{FE}=$ panel regression with fixed effects, $\mathrm{GMM}=$ generalized method of moments, $\mathrm{RE}=$ panel regression with random effects.

Notes: We summarize variables that pass the criteria of the EBA and/or the EDA in Tables 2-6 that include oil countries. Variables with (-) are negatively associated with growth; variables without (-) are positively associated with growth. Inv is investment rate; WR is working-age population; Cris is the share of years in a period in which the country in question was in banking or currency crisis; NFDI is accumulated non-FDI inflows; GDbt is government debt to GDP ratio; LDS is lending-to-deposit interest rate spread; SR is sex ratio (male/female) for ages $0-29$.

Source: Authors' calculation.

\section{GROWTH ACCOUNTING}

In Table 8a, we report growth accounting decompositions of aggregate GDP for different income classes of countries. In PWT 9.0, TFP is calculated (for the first time) using labor hours, not number of employees, as the measure of labor input. For countries that do not report labor hours, PWT 9.0 assumes that the average labor hours changed the same way as in the United States over the period. We again categorize countries according to the level of per capita income at the beginning of each decade and whether they moved to another category over the remainder of that period. For present purposes, the 
most relevant results are those for middle-income countries that remained middle income, versus middle-income countries that graduated to high-income status.

In Table 8e, we see that countries moving from middle- to high-income status had positive TFP growth in every decade. This includes even the 1970s, which were notorious for their productivity slump. Countries that graduated to high-income status did better in terms of growth of TFP than the full sample of countries (Table 8a) in all decades except the 1960s, when there are only five such countries.

Human capital input also rises relatively strongly, more rapidly than in the previously and still high-income countries (although not more strongly than in the sample as a whole). We interpret this as reflecting relatively heavy investments in education, and the fact that middle-income countries start out behind in terms of educational attainment.

\section{Table 8: Growth Accounting Decomposition of Aggregate Gross Domestic Product for Different Income Classes}

(a) All incomes

\begin{tabular}{l|cccccc}
\hline & Obs & $\mathrm{Y}$ & $\mathrm{K}$ & $\mathrm{L}$ & $\mathrm{HC}$ & $\mathrm{TFP}$ \\
\hline $1960 \mathrm{~s}$ & 69 & $5.39 \%$ & $2.13 \%$ & $0.78 \%$ & $0.46 \%$ & $2.03 \%$ \\
$1970 \mathrm{~s}$ & 81 & $4.77 \%$ & $2.79 \%$ & $1.05 \%$ & $0.52 \%$ & $0.42 \%$ \\
$1980 \mathrm{~s}$ & 92 & $2.87 \%$ & $1.69 \%$ & $1.14 \%$ & $0.60 \%$ & $-0.56 \%$ \\
$1990 \mathrm{~s}$ & 105 & $2.65 \%$ & $1.63 \%$ & $0.90 \%$ & $0.50 \%$ & $-0.37 \%$ \\
$2000-2009$ & 114 & $3.96 \%$ & $1.92 \%$ & $0.65 \%$ & $0.39 \%$ & $1.01 \%$ \\
$2010-2014$ & 113 & $3.38 \%$ & $2.03 \%$ & $0.77 \%$ & $0.39 \%$ & $0.19 \%$ \\
Total & 630 & $3.90 \%$ & $2.01 \%$ & $0.86 \%$ & $0.45 \%$ & $0.58 \%$ \\
\hline
\end{tabular}

Notes: Y, K, L, HC, and TFP are aggregate output, capital, labor, human capital, and total factor productivity, respectively. Growth accounting decomposition is based on cgdpo (aggregate output), ck (capital), emp (number of persons engaged), avh (average annual hours), and labsh (labor income share), collected from Penn World Table 9.0, for countries that stay low-income countries during the corresponding decade.

Sources: Penn World Tables 9.0; and authors' calculation.

\section{(b) Staying low-income countries}

\begin{tabular}{l|cccccc}
\hline & Obs & Y & K & L & HC & TFP \\
\hline $1960 s$ & 17 & $4.71 \%$ & $1.45 \%$ & $1.00 \%$ & $0.34 \%$ & $1.93 \%$ \\
$1970 s$ & 15 & $4.02 \%$ & $2.03 \%$ & $1.41 \%$ & $0.34 \%$ & $0.24 \%$ \\
$1980 s$ & 21 & $2.85 \%$ & $1.20 \%$ & $1.55 \%$ & $0.57 \%$ & $-0.46 \%$ \\
$1990 \mathrm{~s}$ & 20 & $2.61 \%$ & $1.21 \%$ & $1.64 \%$ & $0.59 \%$ & $-0.82 \%$ \\
$2000-2009$ & 14 & $5.09 \%$ & $1.66 \%$ & $1.33 \%$ & $0.42 \%$ & $1.68 \%$ \\
$2010-2014$ & 12 & $5.29 \%$ & $3.11 \%$ & $1.73 \%$ & $0.62 \%$ & $-0.17 \%$ \\
Total & 99 & $3.91 \%$ & $1.66 \%$ & $1.44 \%$ & $0.48 \%$ & $0.32 \%$ \\
\hline
\end{tabular}

Notes: Y, K, L, HC, and TFP are aggregate output, capital, labor, human capital, and total factor productivity, respectively. Growth accounting decomposition is based on cgdpo (aggregate output), ck (capital), emp (number of persons engaged), avh (average annual hours), and labsh (labor income share), collected from Penn World Table 9.0, for countries that stay low-income countries during the corresponding decade.

Sources: Penn World Tables 9.0; and authors' calculation. 
(c) Moving from low- to middle- and high-income countries

\begin{tabular}{l|cccccc}
\hline & Obs & $\mathrm{Y}$ & $\mathrm{K}$ & $\mathrm{L}$ & $\mathrm{HC}$ & $\mathrm{TFP}$ \\
\hline $1960 \mathrm{~s}$ & 6 & $6.60 \%$ & $2.46 \%$ & $1.10 \%$ & $0.48 \%$ & $2.56 \%$ \\
$1970 \mathrm{~s}$ & 7 & $6.71 \%$ & $3.60 \%$ & $1.59 \%$ & $0.65 \%$ & $0.87 \%$ \\
$1980 \mathrm{~s}$ & 5 & $6.23 \%$ & $3.08 \%$ & $1.83 \%$ & $1.07 \%$ & $0.25 \%$ \\
$1990 \mathrm{~s}$ & 3 & $5.14 \%$ & $2.61 \%$ & $1.40 \%$ & $0.81 \%$ & $0.32 \%$ \\
$2000-2009$ & 9 & $5.77 \%$ & $2.34 \%$ & $0.62 \%$ & $0.46 \%$ & $2.35 \%$ \\
$2010-2014$ & 3 & $4.79 \%$ & $2.45 \%$ & $1.46 \%$ & $-0.27 \%$ & $1.15 \%$ \\
Total & 33 & $6.04 \%$ & $2.78 \%$ & $1.24 \%$ & $0.56 \%$ & $1.46 \%$ \\
\hline
\end{tabular}

Notes: Growth accounting decomposition is for countries that move from low-to middle- or high-income countries during the corresponding decade. Y, K, L, HC, and TFP are aggregate output, capital, labor, human capital, and total factor productivity, respectively. Growth accounting decomposition is based on cgdpo (aggregate output), ck (capital), emp (number of persons engaged), avh (average annual hours), and labsh (labor income share), collected from Penn World Table 9.0, for countries that stay low-income countries during the corresponding decade.

Sources: Penn World Tables 9.0; and authors' calculation.

\section{(d) Staying middle-income countries}

\begin{tabular}{l|cccccc}
\hline & Obs & Y & K & L & HC & TFP \\
\hline $1960 \mathrm{~s}$ & 40 & $5.63 \%$ & $2.42 \%$ & $0.61 \%$ & $0.48 \%$ & $2.12 \%$ \\
$1970 \mathrm{~s}$ & 34 & $5.35 \%$ & $3.22 \%$ & $1.09 \%$ & $0.52 \%$ & $0.52 \%$ \\
$1980 \mathrm{~s}$ & 38 & $2.75 \%$ & $1.86 \%$ & $1.22 \%$ & $0.68 \%$ & $-1.02 \%$ \\
$1990 \mathrm{~s}$ & 42 & $2.68 \%$ & $1.87 \%$ & $0.92 \%$ & $0.54 \%$ & $-0.65 \%$ \\
$2000-2009$ & 43 & $4.17 \%$ & $2.02 \%$ & $0.65 \%$ & $0.43 \%$ & $1.06 \%$ \\
$2010-2014$ & 46 & $4.04 \%$ & $2.31 \%$ & $0.93 \%$ & $0.48 \%$ & $0.31 \%$ \\
Total & 243 & $4.07 \%$ & $2.26 \%$ & $0.89 \%$ & $0.52 \%$ & $0.40 \%$ \\
\hline
\end{tabular}

Notes: Growth accounting decomposition is for countries that stay middle-income countries during the corresponding decade. Y, K, L, HC, and TFP are aggregate output, capital, labor, human capital, and total factor productivity, respectively. Growth accounting decomposition is based on cgdpo (aggregate output), ck (capital), emp (number of persons engaged), avh (average annual hours), and labsh (labor income share), collected from

Penn World Table 9.0, for countries that stay low-income countries during the corresponding decade.

Sources: Penn World Tables 9.0; and authors' calculation.

\section{(e) Moving from middle- to high-income countries}

\begin{tabular}{l|cccccc}
\hline & Obs & $\mathrm{Y}$ & $\mathrm{K}$ & $\mathrm{L}$ & $\mathrm{HC}$ & TFP \\
\hline $1960 \mathrm{~s}$ & 5 & $4.51 \%$ & $1.70 \%$ & $0.97 \%$ & $0.68 \%$ & $1.16 \%$ \\
$1970 \mathrm{~s}$ & 14 & $4.04 \%$ & $2.32 \%$ & $0.11 \%$ & $0.54 \%$ & $1.07 \%$ \\
$1980 \mathrm{~s}$ & 4 & $5.57 \%$ & $2.78 \%$ & $0.72 \%$ & $0.60 \%$ & $1.48 \%$ \\
$1990 \mathrm{~s}$ & 9 & $3.83 \%$ & $2.17 \%$ & $0.60 \%$ & $0.46 \%$ & $0.60 \%$ \\
$2000-2009$ & 11 & $4.22 \%$ & $1.54 \%$ & $0.23 \%$ & $0.40 \%$ & $2.05 \%$ \\
$2010-2014$ & 7 & $4.44 \%$ & $2.61 \%$ & $0.65 \%$ & $0.35 \%$ & $0.83 \%$ \\
Total & 50 & $4.27 \%$ & $2.14 \%$ & $0.44 \%$ & $0.49 \%$ & $1.21 \%$ \\
\hline
\end{tabular}

Notes: Growth accounting decomposition is for countries that move from middle- to high-income countries during the corresponding decade. Notes: Y, K, L, HC, and TFP are aggregate output, capital, labor, human capital, and total factor productivity, respectively. Growth accounting decomposition is based on cgdpo (aggregate output), ck (capital), emp (number of persons engaged), avh (average annual hours), and labsh (labor income share), collected from Penn World Table 9.0, for countries that stay low-income countries during the corresponding decade.

Sources: Penn World Tables 9.0; and authors' calculation. 


\section{(f) Staying high-income countries}

\begin{tabular}{l|cccccr}
\hline & Obs & $\mathrm{Y}$ & $\mathrm{K}$ & $\mathrm{L}$ & $\mathrm{HC}$ & TFP \\
\hline $1960 \mathrm{~s}$ & 1 & $4.61 \%$ & $1.90 \%$ & $1.07 \%$ & $0.40 \%$ & $1.25 \%$ \\
$1970 \mathrm{~s}$ & 10 & $3.67 \%$ & $2.70 \%$ & $1.11 \%$ & $0.62 \%$ & $-0.77 \%$ \\
$1980 \mathrm{~s}$ & 21 & $2.20 \%$ & $1.21 \%$ & $0.62 \%$ & $0.41 \%$ & $-0.04 \%$ \\
$1990 \mathrm{~s}$ & 28 & $3.14 \%$ & $1.48 \%$ & $0.52 \%$ & $0.34 \%$ & $0.80 \%$ \\
$2000-2009$ & 36 & $2.82 \%$ & $1.92 \%$ & $0.54 \%$ & $0.31 \%$ & $0.06 \%$ \\
$2010-2014$ & 45 & $1.94 \%$ & $1.33 \%$ & $0.32 \%$ & $0.28 \%$ & $0.01 \%$ \\
Total & 141 & $2.58 \%$ & $1.59 \%$ & $0.52 \%$ & $0.34 \%$ & $0.12 \%$ \\
\hline
\end{tabular}

Notes: Growth accounting decomposition is for countries that stay high-income countries during the corresponding decade. Y, K, L, HC, and TFP are aggregate output, capital, labor, human capital, and total factor productivity, respectively. Growth accounting decomposition is based on cgdpo (aggregate output), ck (capital), emp (number of persons engaged), avh (average annual hours), and labsh (labor income share), collected from Penn World Table 9.0, for countries that stay low-income countries during the corresponding decade.

Sources: Penn World Tables 9.0; and authors' calculation.

Finally, the physical capital stock grows more rapidly in countries that graduate to high-income status than in the incumbent high-income countries in overall averages (2.14\% versus $1.59 \%)$. This is particularly true in the 1980s, 1990s, and 2010-2014. Again, not too much should probably be made of the 1960s exception, given the small sample size. From 2000 to 2009 was a period when a number of high-income countries experienced investment booms in the form of construction/real estate bubbles, not something that countries seeking to graduate to high-income status would necessarily want to emulate.

Comparing middle-income countries that graduate (Table 8e) with those that do not (Table 8d) also reveals some interesting contrasts. TFP growth is slower in countries that "remain trapped" in middle-income status. This is consistently true with the exception only of the anomalous 1960s. More surprisingly, the increase in human capital formation is faster in countries that "remain trapped" in middle-income status; this suggests that investment in education is no silver bullet-no guarantee of graduating. The rate of growth of the capital stock is also faster in countries that "remain trapped," although this variable jumps around a lot, investment being volatile, which causes us to hesitate in drawing firm conclusions.

Thus, this growth accounting decomposition suggests that countries graduating to high-income status (countries escaping the middle-income trap) exploit multiple advantages, including relatively fast TFP growth, relatively rapid growth of human capital, and relatively high fixed investment. But rapid growth of the fixed and human capital stocks (brute force investment) are not guarantees of escaping the middle-income trap. While we find evidence for both "perspiration" (investment) and "inspiration" (productivity growth), evidence for the latter is more robust in some cases.

\section{SECTORAL COMPARISONS}

In this section, we separate aggregate economic growth into the growth of the manufacturing and service sectors, exploring the hypotheses that the two sectors are prone to accelerate and decelerate at different times for different reasons. ${ }^{2}$

2 Tables reporting economic factor associated with manufacturing and services growth are in the appendix tables. 
Results are somewhat sensitive to which of the two procedures is used to identify robust regressors. For manufacturing, EBA points to the importance of the share of government consumption in GDP, which is negatively associated with the subsequent growth of per capita GDP in middle-income countries; this is consistent with worries about the growth effects of bloated public sectors whose spending focuses on transfer payments in particular, something that is a growing problem in a number of middle-income countries. In contrast, neither government consumption nor any of the other candidate variables is identified using EBA when we turn to the service sector.

EDA points to a number of variables as important for the growth of the manufacturing sector in middle-income countries when the relevant relationship is estimated using random effects. These include the share of the population that is of working age, the male-to-female sex ratio, bank credit as a share of bank deposits, and the strength of the political system, which is the political constraint index, where higher values are associated with more robust political systems). All of these variables are positively associated with growth, as well as the Gini coefficient, which is negatively associated with growth. For the service sector, it points to the male-to-female sex ratio and lending-to-deposit interest rate spread as positively associated with growth, which is a bit puzzling.

Overall, it is easier to identify the circumstances under which the growth of the manufacturing sector slows in middle-income countries; those circumstances include unfavorable demographics (a low share of the working-age population, a high ratio of female-to-male workers), a banking sector that provides relatively little credit to producers, a high level of income inequality, and a political system in which the executive is only weakly constrained, along perhaps with a large public sector focused on transfers and other current payments. By comparison, it is harder to characterize the circumstances under which service sector growth slows or stagnates in such economies. ${ }^{3}$

We would note again that the elusive nature of fluctuations in growth, in this case in service sector growth, are not specific to middle-income countries. The same result, namely that there appears to be relatively few significant correlates of changes in service sector growth-perhaps the gender balance, or perhaps none of the variables considered in the present analysis, depending on the technique used to identify robust regressors - applies equally to low-, middle-, and high-income countries, or so it would appear from the appendix tables. Institutional capabilities and human capital are essential for sustained service sector growth (as argued by, inter alia, Rodrik 2012). We could not include these factors as regressors since few reasonable proxies exist for these variables for a wide coverage of countries and a relatively long period. 4

\section{CRISES AND GROWTH}

Tables 3-7 highlighted a possible role for banking and currency crises in affecting growth in middleincome countries generally. To investigate their long-term impact, in Table 9 we add to our earlier growth regressions indicator variables for crises not just in the current decade (that for which the dependent variable is defined) and also the preceding decade. We then estimated three sets of regressions that included all of the significant variables in Appendix Table A1, except for accumulated non-FDI inflows and government debt (for which there are a substantial number of missing

3 In the case of services, there is a bit of evidence favoring demographic explanations, as in the case of manufacturing, but not much.

4 While we included years of schooling as a proxy for human capital, the quality of human capital that may play a more important role for service sector growth is not adequately captured by this variable. 
observations). In the first set of regressions (the first three columns), the crisis variables-current and lagged crises - were measured as the share of years in a period in which the country in question was in crisis, i.e., the number of years with either banking or currency crises divided by 10 for the decade observations and by 4 for the last period. In the second set of regressions (the second set of three columns), we use a simple dummy variable of whether a country experienced a crisis in a decade. Finally, in the last set of regressions (the last three columns), the regressors include an additional variable based only on the last 3 years of the previous decade (toward the end of the preceding period).

Table 9a shows the results for the full sample. Experiencing a crisis in the current decade has a negative impact on economic growth (the coefficients in question are significantly different from zero at the $99 \%$ confidence level), something that will not surprise aficionados of the crisis literature. In contrast, experiencing a crisis in the previous decade, irrespective of how this is measured (average years in crisis or a decade incidence dummy), does not appear to affect growth either positively or negatively, contrary to what has been suggested in some earlier literature. This same finding obtains whether lagged crises are recorded over the entire previous decade or in its final 3 years only. One of the nine coefficients on lagged crises is positive, consistent with the Tornell and Westermann (2005) view. But the safest conclusion appears to be that crises have no long-run impact on growth, either positive or negative.

When we focus exclusively on middle-income countries (Table 9b), basically the same results again come through. 
Table 9: The Impact of Crises on Long-Run Growth

\section{(a) All incomes}

\begin{tabular}{|c|c|c|c|c|c|c|c|c|c|}
\hline & \multicolumn{3}{|c|}{$\begin{array}{c}\text { (1) Current and Predecade } \\
\text { Average Crisis }\end{array}$} & \multicolumn{3}{|c|}{$\begin{array}{l}\text { (2) Current and Predecade } \\
\text { Crises Dummies }\end{array}$} & \multicolumn{3}{|c|}{$\begin{array}{c}\text { (3) Average Crisis } \\
\text { of Last } 3 \text { Years of Predecade }\end{array}$} \\
\hline & RE & FE & GMM & RE & $\mathrm{FE}$ & GMM & RE & $\mathrm{FE}$ & GMM \\
\hline Initial income level & $\begin{array}{l}-0.014^{* * *} \\
{[0.002]}\end{array}$ & $\begin{array}{l}-0.024^{* * *} \\
{[0.004]}\end{array}$ & & $\begin{array}{l}-0.015^{* * *} \\
{[0.002]}\end{array}$ & $\begin{array}{l}-0.025^{* * *} \\
{[0.004]}\end{array}$ & & $\begin{array}{l}-0.016^{* * *} \\
{[0.003]}\end{array}$ & $\begin{array}{l}-0.031^{* * *} \\
{[0.004]}\end{array}$ & \\
\hline Years of schooling & $\begin{array}{l}0.013^{* * *} \\
{[0.004]}\end{array}$ & $\begin{array}{c}0.006 \\
{[0.005]}\end{array}$ & $\begin{array}{l}0.296^{* * *} \\
{[0.105]}\end{array}$ & $\begin{array}{l}0.013^{* * *} \\
{[0.004]}\end{array}$ & $\begin{array}{c}0.004 \\
{[0.006]}\end{array}$ & $\begin{array}{l}0.280^{* *} \\
{[0.116]}\end{array}$ & $\begin{array}{l}0.015^{* * *} \\
{[0.006]}\end{array}$ & $\begin{array}{c}0.003 \\
{[0.006]}\end{array}$ & $\begin{array}{c}0.182 \\
{[0.130]}\end{array}$ \\
\hline Investment share & $\begin{array}{l}0.042^{* *} \\
{[0.017]}\end{array}$ & $\begin{array}{l}0.044^{* *} \\
{[0.019]}\end{array}$ & $\begin{array}{l}-0.535 \\
{[0.510]}\end{array}$ & $\begin{array}{l}0.043^{* *} \\
{[0.018]}\end{array}$ & $\begin{array}{l}0.047^{* *} \\
{[0.020]}\end{array}$ & $\begin{array}{l}-0.758 \\
{[0.572]}\end{array}$ & $\begin{array}{l}0.048^{* *} \\
{[0.023]}\end{array}$ & $\begin{array}{r}0.050^{*} \\
{[0.025]}\end{array}$ & $\begin{array}{c}0.075 \\
{[0.556]}\end{array}$ \\
\hline Working-age population share & $\begin{array}{l}0.145^{* * *} \\
{[0.033]}\end{array}$ & & $\begin{array}{c}0.851 \\
{[0.834]}\end{array}$ & $\begin{array}{l}0.151^{* * *} \\
{[0.033]}\end{array}$ & & $\begin{array}{l}0.897 \\
{[1.017]}\end{array}$ & $\begin{array}{l}0.143^{* * *} \\
{[0.037]}\end{array}$ & & $\begin{array}{l}0.791 \\
{[1.224]}\end{array}$ \\
\hline Average crisis & $\begin{array}{l}-0.014^{* * *} \\
{[0.004]}\end{array}$ & $\begin{array}{l}-0.015^{* * *} \\
{[0.004]}\end{array}$ & $\begin{array}{l}-0.267^{* * *} \\
{[0.056]}\end{array}$ & & & & $\begin{array}{l}-0.013^{* * *} \\
{[0.004]}\end{array}$ & $\begin{array}{l}-0.013^{* * *} \\
{[0.004]}\end{array}$ & $\begin{array}{l}-0.245^{* * *} \\
{[0.062]}\end{array}$ \\
\hline Lagged average crisis & $\begin{array}{l}0.008^{* *} \\
{[0.004]}\end{array}$ & $\begin{array}{c}0.005 \\
{[0.004]}\end{array}$ & $\begin{array}{l}-0.040 \\
{[0.083]}\end{array}$ & & & & & & \\
\hline Lagged per capita real GDP & & & $\begin{array}{c}0.991^{* * *} \\
{[0.096]}\end{array}$ & & & $\begin{array}{l}1.035^{* * *} \\
{[0.116]}\end{array}$ & & & $\begin{array}{l}0.949^{* * *} \\
{[0.092]}\end{array}$ \\
\hline Crisis dummy & & & & $\begin{array}{l}-0.006^{* * *} \\
{[0.002]}\end{array}$ & $\begin{array}{l}-0.009^{* * *} \\
{[0.002]}\end{array}$ & $\begin{array}{l}-0.118^{* * *} \\
{[0.036]}\end{array}$ & & & \\
\hline Lagged crisis dummy & & & & $\begin{array}{c}0.002 \\
{[0.003]}\end{array}$ & $\begin{array}{c}0.000 \\
{[0.002]}\end{array}$ & $\begin{array}{l}-0.050 \\
{[0.044]}\end{array}$ & & & \\
\hline Average crisis of last 3 years of predecade & & & & & & & $\begin{array}{c}0.004 \\
{[0.003]}\end{array}$ & $\begin{array}{c}0.003 \\
{[0.003]}\end{array}$ & $\begin{array}{c}0.037 \\
{[0.051]}\end{array}$ \\
\hline $\mathrm{R}^{2}$ & 0.33 & 0.371 & & 0.3182 & 0.367 & & 0.314 & 0.412 & \\
\hline Observations & 294 & 294 & 294 & 294 & 294 & 294 & 236 & 236 & 236 \\
\hline Countries & 66 & 66 & 66 & 66 & 66 & 66 & 66 & 66 & 66 \\
\hline
\end{tabular}

$\mathrm{FE}=$ panel regression with fixed effects, GDP = gross domestic product, $\mathrm{GMM}=$ generalized method of moments, $\mathrm{RE}$ = panel regression with random effects.

Notes: Column (1) reports panel regressions with random effects and fixed effects, and dynamic-panel GMM estimation when the current and lagged average crises are used as explanatory

variables. Column (2) reports the same regressions when the current and lagged crisis dummies are used. The crisis dummy takes one if any year of the current decade experiences a crisis. Finally, column (3) reports the same three regressions when the average crisis in the last 3 years of the predecade is used. Oil-producing countries are included. ${ }^{*}=$ statistically significant at the $10 \%$ level.

${ }^{* *}=$ statistically significant at the $5 \%$ level. ${ }^{* * *}=$ statistically significant at the $1 \%$ level.

Source: Authors' calculation. 


\section{(b) Middle-income countries}

\begin{tabular}{|c|c|c|c|c|c|c|c|c|c|}
\hline & \multicolumn{3}{|c|}{$\begin{array}{c}\text { (1) Current and Predecade Average } \\
\text { Crisis }\end{array}$} & \multicolumn{3}{|c|}{$\begin{array}{c}\text { (2) Current and Predecade Crises } \\
\text { Dummies }\end{array}$} & \multicolumn{3}{|c|}{$\begin{array}{l}\text { (3) Average Crisis of Last } 3 \text { Years } \\
\text { of Predecade }\end{array}$} \\
\hline & RE & $\mathrm{FE}$ & GMM & RE & FE & GMM & $\mathrm{RE}$ & FE & GMM \\
\hline \multirow[t]{2}{*}{ Initial income level } & $-0.017^{* * *}$ & $-0.036^{* * *}$ & & $-0.017^{* * *}$ & $-0.034^{* * *}$ & & $-0.019^{* * *}$ & $-0.036^{* * *}$ & \\
\hline & {$[0.004]$} & {$[0.006]$} & & {$[0.005]$} & {$[0.006]$} & & {$[0.006]$} & {$[0.006]$} & \\
\hline \multirow[t]{2}{*}{ Years of schooling } & 0.006 & -0.014 & -0.092 & 0.006 & -0.012 & -0.143 & 0.006 & -0.013 & -0.153 \\
\hline & {$[0.004]$} & {$[0.010]$} & {$[0.150]$} & {$[0.004]$} & {$[0.009]$} & {$[0.157]$} & {$[0.006]$} & {$[0.012]$} & {$[0.094]$} \\
\hline \multirow[t]{2}{*}{ Investment share } & $0.040^{* *}$ & 0.004 & -0.706 & $0.038^{* *}$ & 0.005 & -0.501 & 0.040 & 0.023 & -0.112 \\
\hline & {$[0.019]$} & {$[0.025]$} & {$[0.451]$} & {$[0.019]$} & {$[0.029]$} & {$[0.586]$} & {$[0.025]$} & {$[0.024]$} & {$[0.495]$} \\
\hline \multirow[t]{2}{*}{ Working-age population share } & $0.180^{* * *}$ & -0.059 & $1.757^{*}$ & $0.174^{* * *}$ & -0.088 & $2.228^{* *}$ & $0.183^{* * *}$ & -0.060 & $2.143^{* *}$ \\
\hline & {$[0.038]$} & {$[0.058]$} & {$[1.010]$} & {$[0.041]$} & {$[0.054]$} & {$[1.013]$} & {$[0.050]$} & {$[0.071]$} & {$[1.092]$} \\
\hline \multirow[t]{2}{*}{ Average crisis } & $-0.013^{* *}$ & -0.006 & $-0.263^{* * *}$ & & & & -0.010 & -0.005 & $-0.240^{* *}$ \\
\hline & {$[0.007]$} & {$[0.006]$} & {$[0.082]$} & & & & {$[0.007]$} & {$[0.007]$} & {$[0.106]$} \\
\hline \multirow[t]{2}{*}{ Lagged average crisis } & 0.003 & -0.005 & -0.099 & & & & & & \\
\hline & {$[0.004]$} & {$[0.005]$} & {$[0.085]$} & & & & & & \\
\hline \multirow[t]{2}{*}{ Lagged per capita real GDP } & & & $0.842^{* * *}$ & & & $0.823^{* * *}$ & & & $0.827^{* * *}$ \\
\hline & & & {$[0.092]$} & & & {$[0.102]$} & & & {$[0.105]$} \\
\hline \multirow[t]{2}{*}{ Crisis dummy } & & & & $-0.008^{* * *}$ & $-0.008^{* *}$ & $-0.082^{*}$ & & & \\
\hline & & & & {$[0.003]$} & {$[0.004]$} & {$[0.042]$} & & & \\
\hline \multirow[t]{2}{*}{ Lagged crisis dummy } & & & & -0.001 & -0.004 & -0.041 & & & \\
\hline & & & & {$[0.004]$} & {$[0.004]$} & {$[0.058]$} & & & \\
\hline \multirow[t]{2}{*}{ Average crisis of last 3 years of predecade } & & & & & & & 0.001 & -0.001 & 0.003 \\
\hline & & & & & & & {$[0.004]$} & {$[0.004]$} & {$[0.066]$} \\
\hline $\mathrm{R}^{2}$ & 0.407 & 0.525 & & 0.408 & 0.546 & & 0.366 & 0.585 & \\
\hline Observations & 168 & 168 & 168 & 168 & 168 & 168 & 127 & 127 & 127 \\
\hline Countries & 59 & 59 & 59 & 59 & 59 & 59 & 54 & 54 & 54 \\
\hline
\end{tabular}

$\mathrm{FE}=$ panel regression with fixed effects, $\mathrm{GDP}=$ gross domestic product, $\mathrm{GMM}=$ generalized method of moments, $\mathrm{RE}=$ panel regression with random effects.

Notes: The sample includes observations for which the corresponding country belongs to middle-income countries at the initial year of the decade. Oil-producing countries are also included.

Column (1) reports panel regressions with random effects and fixed effects, and dynamic-panel GMM estimation when the current and lagged average crises are used as explanatory variables.

Column (2) reports the same regressions when the current and lagged crisis dummies are used. The crisis dummy takes one if any year of the current decade experiences a crisis. Finally, column

(3) reports the same three regressions when the average crisis in the last 3 years of the predecade is used. Oil-producing countries are included. ${ }^{*}=$ statistically significant at the $10 \%$ level.

${ }^{* *}=$ statistically significant at the $5 \%$ level. ${ }^{* *}=$ statistically significant at the $1 \%$ level.

Source: Authors' calculation. 


\section{CONCLUSIONS}

In this paper, we have summarized some broad stylized facts about growth in middle-income countries and the determinants - positive and negative-of the potential transition to high-income status.

A key finding is that the economic factors associated with growth differ between middle-income and other countries. One distinction is between low- and middle-income countries. We find that the efficiency of the financial system is more importantly related to the growth rate in low-income countries. We consider a number of different measures of financial development and, consistently, find that this variable matters less, relative to other factors, as one moves up the per capita income scale. At this point, other variables gain a growing role; these include whether the country experiences a banking or currency crisis (which affects current growth negatively), the extent of non-FDI capital inflows (which affects growth negatively), and government debt as a share of GDP (which again affects growth negatively). In addition, we find that demographic variables are especially important for growth in low-income countries, less so in middle-income countries.

A complementary approach to these same questions is growth accounting. Our growth accounting analysis suggests that countries escaping the middle-income trap are characterized by relatively fast TFP growth, relatively rapid growth of human capital, and relatively high fixed investment. But while we find evidence for both "perspiration" (rapid rates of capital formation) and "inspiration" (rapid productivity growth), the evidence for the latter is more robust in some sense.

Distinguishing the manufacturing sector from the service sector turns out to be easier to account for the successful growth of manufacturing in middle-income countries. Success or failure at growing the manufacturing sector appears to hinge on a number of specific labor market variables, financial market variables, and public finance variables (debts and deficits). The growth of the service sector, in contrast, is more difficult to account for (more difficult to associate with these and other variables). We interpret this as suggesting that other, more difficult-to-measure institutional variables are important for sustaining service sector growth. This does not mean that the transition from manufacturing- to services-led growth is impossible for middle-income countries, but success at this transition may not depend on a simple policy formula.

Finally, we confirm that financial crises are bad for growth (not surprisingly) at the time when they occur. But there is little evidence that such crises have a long-lived impact, either positive or negative, over a period of decades. While financial crises are best avoided, sustaining economic growth in middle-income countries and successfully completing the transition to high-income status require policy makers and societies to continue to focus on the fundamental determinants of growth.

Our findings have a number of significant implications for developing Asia in general and the PRC in particular. For one, the positive effect of a relatively young, low-income population on the region's growth in the past may outweigh the adverse effect of an older, middle-income population at present. Returns to further finance sector development may decline now that the region is largely middle income. Combined with our finding that banking crisis and non-FDI capital flows harm growth, these suggest a need for a cautious and gradual approach to financial liberalization. A tradition of fiscal prudence served Asia well in the past, and will serve it well in the future. Above all, our evidence confirms the central importance of TFP growth in Asia's quest to avoid the middle-income trap that has afflicted many other parts of the developing world. That is, to move beyond middle income, the region must shift toward a growth paradigm in which productivity growth takes center stage. Investment in both physical and human capital will also help the region to continue to grow. 


\section{APPENDIXES}

Table A1: Sources and Definitions of Variables

\begin{tabular}{|c|c|c|}
\hline Variables & Description and Construction & Data Source \\
\hline Per capita real GDP growth (\%) & Log difference of per capita real GDP at constant 2011 national prices & Penn World Table 9.0 \\
\hline Years of schooling & $\ln \left(\right.$ Years of Schooling $\left.+\sqrt{\text { Years of Schooling }^{2}+1}\right)$ & Barro-Lee Database \\
\hline Investment share & Share of gross capital formation at current PPPs & Penn World Table 9.0 \\
\hline Working-age population share & Percentage of working-age population, both sexes combined & United Nations \\
\hline Working-age population growth (\%) & Log difference of working-age population, both sexes combined & United Nations \\
\hline Paved roads & Paved roads in kilometers per thousand workers & Calderón et al. (2014), provided by Han and Wei \\
\hline Electricity-generating capacity & Electricity generating capacity in gigawatts per thousand workers & Calderón et al. (2014), provided by Han and Wei \\
\hline Railway (kilometer) & Railways in kilometers per thousand workers & Calderón et al. (2014), provided by Han and Wei \\
\hline Inflation & $\ln \left(\right.$ Inflation $\left.+\sqrt{\text { Inflation }^{2}+1}\right)$, consumer price index (annual $\left.\%\right)$ & World Bank's World Development Indicators \\
\hline Domestic credit to private sector & $\begin{array}{l}\text { Total credit to private sector extended by private banks and other financial } \\
\text { institutions }\end{array}$ & Financial Development and Structure Dataset \\
\hline Bank credit-to-deposit ratio & Bank credit to bank deposits (\%) & $\begin{array}{l}\text { World Bank: Global Financial Development } \\
\text { Database }\end{array}$ \\
\hline $\begin{array}{l}\text { Lending-to-deposit interest rate } \\
\text { spread }\end{array}$ & Bank lending deposit spread & $\begin{array}{l}\text { World Bank: Global Financial Development } \\
\text { Database }\end{array}$ \\
\hline Banking or currency crisis & The share of years in a period in which the country in question was in crisis & Carmen Reinhart and Rogoff Database \\
\hline Government debt share & $\begin{array}{l}\text { Total gross central government debt/GDP for all but Italy, the Netherlands, and New } \\
\text { Zealand for which we use total gross general government debt/GDP }\end{array}$ & Carmen Reinhart Database \\
\hline Conflicts index & Weighted conflict index & Cross-National Time-Series Data Archive \\
\hline Political constraints & Political constraint indexes "Polcon V" & Henisz $(2000,2002)$, provided by Han and Wei \\
\hline Accumulated FDI inflows & Share of gross FDI inflow to GDP in the 4 years ahead of each decade & Bluedorn et al., provided by Han and Wei \\
\hline Accumulated non-FDI inflows & Share of gross non-FDI inflow to GDP in the 4 years ahead of each decade & Bluedorn et al., provided by Han and Wei \\
\hline Trade share & $\%$ of GDP & World Bank's World Development Indicators \\
\hline Gini index & In equivalized household disposable income & Standardized World Income Inequality Database 4.0 \\
\hline Sex ratio & Sex ratio (male/female) for ages $0-29$ & Han and Wei (2016) \\
\hline Government consumption share & Share of government consumption at current PPPs & Penn World Table 9.0 \\
\hline Human capital & Human capital index & Penn World Table 9.0 \\
\hline Labor share & Share of labor compensation in GDP at current national prices & Penn World Table 9.0 \\
\hline Number of persons engaged & In million & Penn World Table 9.0 \\
\hline Average annual hours & Average annual hours worked by persons engaged & Penn World Table 9.0 \\
\hline Capital stock & Capital stock at constant 2011 national prices ( $\$$ million, 2011) & Penn World Table 9.0 \\
\hline Total factor productivity & Constant national prices $(2011=1)$ & Penn World Table 9.0 \\
\hline
\end{tabular}

$\mathrm{FDI}=$ foreign direct investment, $\mathrm{GDP}=$ gross domestic product, $\mathrm{PPP}=$ purchasing power parity .

Source: Authors' compilation. 
Table A2: All Country and Decade Observations: Oil Countries Excluded

(a) Extreme-bounds analysis

\begin{tabular}{|c|c|c|c|c|c|c|c|c|c|c|}
\hline & Variable & & ta & SE & t-stat & Obs & Groups & $\mathrm{R}^{2}$ & $\begin{array}{c}\text { Other } \\
\text { Variables }\end{array}$ & NS \\
\hline \multirow{12}{*}{ RE } & \multirow{3}{*}{$\begin{array}{l}\text { Investment } \\
\text { share }\end{array}$} & high & 0.122 & [0.037] & 3.33 & 92 & 48 & 0.336 & v11 v13 v15 & \multirow{3}{*}{73} \\
\hline & & base & 0.043 & [0.019] & 2.30 & 647 & 123 & 0.167 & & \\
\hline & & low & 0.009 & {$[0.030]$} & 0.31 & 118 & 72 & 0.447 & v2 v10 v13 & \\
\hline & \multirow{3}{*}{ Work ratio } & high & 0.441 & {$[0.056]$} & 7.88 & 165 & 83 & 0.500 & v3 v13 v15 & \multirow{3}{*}{0} \\
\hline & & base & 0.172 & {$[0.030]$} & 5.76 & 641 & 122 & 0.205 & & \\
\hline & & low & 0.066 & {$[0.045]$} & 1.46 & 132 & 35 & 0.472 & v11 v12 v18 & \\
\hline & \multirow{3}{*}{$\begin{array}{l}\text { Banking or } \\
\text { currency crisis }\end{array}$} & high & -0.005 & [0.004] & -1.15 & 151 & 59 & 0.392 & v2 v16 v17 & \multirow{3}{*}{4} \\
\hline & & base & -0.016 & {$[0.004]$} & -3.84 & 289 & 63 & 0.171 & & \\
\hline & & low & -0.029 & {$[0.006]$} & -4.60 & 63 & 40 & 0.284 & v9 v10 v13 & \\
\hline & \multirow{3}{*}{$\begin{array}{l}\text { Accumulated } \\
\text { non-FDI inflows }\end{array}$} & high & -0.001 & {$[0.006]$} & -0.24 & 69 & 31 & 0.552 & v2 v12 v13 & \multirow{3}{*}{37} \\
\hline & & base & -0.015 & {$[0.004]$} & -3.25 & 362 & 115 & 0.173 & & \\
\hline & & low & -0.034 & {$[0.011]$} & -3.21 & 109 & 65 & 0.288 & v10 v13 v15 & \\
\hline \multirow{6}{*}{$\mathrm{FE}$} & \multirow{3}{*}{$\begin{array}{l}\text { Banking or } \\
\text { currency crisis }\end{array}$} & high & -0.005 & {$[0.005]$} & -1.11 & 156 & 59 & 0.448 & v2 v3 v16 & \multirow{4}{*}{1} \\
\hline & & base & -0.016 & [0.004] & -3.94 & 289 & 63 & 0.364 & & \\
\hline & & low & -0.026 & {$[0.004]$} & -5.70 & 55 & 27 & 0.574 & v12 v13 v15 & \\
\hline & \multirow{3}{*}{$\begin{array}{l}\text { Accumulated } \\
\text { non-FDI inflows }\end{array}$} & high & 0.02 & {$[0.011]$} & 1.86 & 63 & 39 & 0.798 & v10 v11 v13 & \\
\hline & & base & -0.019 & {$[0.006]$} & -3.27 & 362 & 115 & 0.322 & & \multirow[t]{2}{*}{93} \\
\hline & & low & -0.044 & {$[0.017]$} & -2.52 & 161 & 81 & 0.402 & v3 v13 & \\
\hline \multirow{6}{*}{ GMM } & \multirow{3}{*}{$\begin{array}{l}\text { Banking or } \\
\text { currency crisis }\end{array}$} & high & 0.019 & {$[0.178]$} & 0.11 & 89 & 33 & & v2 v12 v16 & \multirow{3}{*}{19} \\
\hline & & base & -0.249 & [0.049] & -5.08 & 289 & 63 & & & \\
\hline & & low & -0.479 & {$[0.108]$} & -4.41 & 92 & 48 & & v13 v15 v19 & \\
\hline & \multirow{3}{*}{$\begin{array}{l}\text { Accumulated } \\
\text { non-FDI inflows }\end{array}$} & high & 0.177 & {$[0.198]$} & 0.90 & 86 & 32 & & v1 v4 v12 & \multirow{3}{*}{78} \\
\hline & & base & -0.137 & {$[0.034]$} & -4.10 & 363 & 115 & & & \\
\hline & & low & -0.741 & $\lceil 0.434\rceil$ & -1.70 & 91 & 48 & & v3 v11 v13 & \\
\hline
\end{tabular}

$\mathrm{FDI}=$ foreign direct investment, $\mathrm{GDP}=$ gross domestic product, $\mathrm{SE}=$ standard error, $\mathrm{v} 1=$ investment share, $\mathrm{v2}=$ working-age population share, $\mathrm{v} 3$ = working-age population growth, $\mathrm{v} 4$ = paved roads (kilometer [km] per number of workers), $\mathrm{v} 9=$ bank credit-to-deposit ratio, v10 = lendingto-deposit interest rate spread, v11 = banking or currency crisis (number of years with either banking of currency crises divided by 10 for the decade observations and by 4 for the last period [2010-2014]), v12 = government debt share (debt-to-GDP ratio), v13 = conflict index,

$\mathrm{v} 15=$ accumulated FDI inflows ( 4 years ahead of each decade), v16 = accumulated non-FDI inflows ( 4 years ahead of each decade), v17 = trade share (trade [exports + imports] to GDP ratio), v18 = Gini index, v19 = gender ratio for ages 0-29.

Notes: This is the same table as Table 2a except that the sample does not include observations from oil countries. All country/decade observations are used for estimation. RE refers to panel regression with random effects, FE refers to panel regression with fixed effects, and $\mathrm{GMM}$ refers to generalized method of moments approach to dynamic panel regression. The base Beta reports the estimated coefficient of variable from the regression with the variable and the always-included variables (initial income and years of schooling) used as regressors. The high Beta reports the extreme high bound of the estimated coefficient of variable of interest; the low Beta reports the extreme low bound of variable of interest. Other variables are the variables that are included besides the variable of interest and the always-included variables, in producing the extreme bound coefficient. We report variables if they are insignificant at the $5 \%$ level (one sided) less than $10 \%$ of all the sensitivity regressions. NS is the number of regressions where the estimated coefficient is not significant at the $5 \%$ level (one sided).

Source: Authors' calculation. 


\section{(b) Entire distribution analysis}

\begin{tabular}{|c|c|c|c|c|c|c|}
\hline & Variable & Beta & $\mathrm{df}$ & SD & $\begin{array}{l}\text { Mean of } \\
\text { P-Value }\end{array}$ & $\begin{array}{l}\mathrm{P}-\mathrm{V} \text { alue of } \\
\text { the Mean }\end{array}$ \\
\hline \multirow{5}{*}{ RE } & Investment share & 0.057 & 263.185 & 0.025 & 0.027 & 0.012 \\
\hline & Work ratio & 0.211 & 263.110 & 0.046 & 0.001 & 0.000 \\
\hline & Banking or currency crisis & -0.016 & 168.472 & 0.005 & 0.004 & 0.001 \\
\hline & Government debt share & -0.010 & 112.343 & 0.006 & 0.117 & 0.047 \\
\hline & Accumulated non-FDI inflows & -0.010 & 188.794 & 0.005 & 0.019 & 0.014 \\
\hline \multirow{4}{*}{$\mathrm{FE}$} & Investment share & 0.049 & 79.007 & 0.029 & 0.100 & 0.045 \\
\hline & Work ratio & 0.152 & 78.985 & 0.065 & 0.045 & 0.011 \\
\hline & Banking or currency crisis & -0.015 & 52.469 & 0.005 & 0.004 & 0.001 \\
\hline & Accumulated non-FDI inflows & -0.011 & 74.882 & 0.005 & 0.035 & 0.027 \\
\hline \multirow{2}{*}{ GMM } & Banking or currency crisis & -0.249 & 168.472 & 0.076 & 0.007 & 0.001 \\
\hline & Accumulated non-FDI inflows & -0.165 & 188.993 & 0.086 & 0.030 & 0.028 \\
\hline
\end{tabular}

$\mathrm{FDI}=$ foreign direct investment, $\mathrm{FE}=$ panel regression with fixed effects, $\mathrm{GMM}=$ generalized method of moments, $\mathrm{RE}=$ panel regression with random effects.

Notes: This is the same table as Table $2 \mathrm{~b}$ except that the sample does not include observations from oil countries. Beta, $\mathrm{df}$, and SD are weighted averages of the estimated coefficients, degrees of freedom, and standard deviations, respectively, using the likelihood values as weights in the sensitivity regressions for each variable reported in Table 2a. Mean of $p$-value is weighted average of $p$ values; $p$ value of the mean is $p$-value of the average coefficient using the average standard errors that are calculated from the weighted average of estimated variances. We report variables only when the mean of $p$-value or $p$-value of the mean is less than 05 .

Source: Authors' calculation.

\section{Table A3: Countries in the Low-Income Class at the Initial Year: Oil Countries Excluded}

\section{(a) Extreme-bounds analysis}

\begin{tabular}{|c|c|c|c|c|c|c|c|c|c|c|}
\hline & Variable & & Beta & SE & t-stat & Obs & Groups & $\mathrm{R}^{2}$ & $\begin{array}{c}\text { Other } \\
\text { Variables }\end{array}$ & NS \\
\hline \multirow{6}{*}{ RE } & \multirow{4}{*}{$\begin{array}{l}\text { Lending-to- } \\
\text { deposit rate } \\
\text { spread }\end{array}$} & high & -0.025 & [0.098] & -0.26 & 43 & 25 & 0.616 & v1 v8 v16 & \multirow{3}{*}{63} \\
\hline & & base & -0.143 & [0.068] & -2.10 & 70 & 30 & 0.435 & & \\
\hline & & low & -0.514 & [0.171] & -3.01 & 34 & 20 & 0.679 & v9 v16 v18 & \\
\hline & & high & 0.64 & [0.239] & 2.68 & 24 & 11 & 0.512 & v11 v17 v18 & \multirow{3}{*}{114} \\
\hline & \multirow[t]{2}{*}{ Sex ratio } & base & 0.141 & {$[0.054]$} & 2.61 & 191 & 52 & 0.259 & & \\
\hline & & low & -0.381 & {$[0.219]$} & -1.74 & 43 & 19 & 0.517 & v2 v6 v11 & \\
\hline
\end{tabular}

$\mathrm{FDI}=$ foreign direct investment, GDP = gross domestic product, $\mathrm{RE}=$ panel regression with random effects, $\mathrm{SE}=$ standard error, $\mathrm{v} 1=$ investment share, $\mathrm{v} 2$ = working-age population share, $\mathrm{v} 6=$ railway $(\mathrm{km}$ per number of workers), $\mathrm{v} 8=$ domestic credit to private sector (extended by private banks and other financial institutions), $\mathrm{v} 9=$ bank credit-to-deposit ratio, $\mathrm{v} 11$ = banking or currency crisis (number of years with either banking of currency crises divided by 10 for the decade observations and by 4 for the last period [2010-2014]), $\mathrm{v} 16=$ accumulated non-FDI inflows (4 years ahead of each decade), $\mathrm{v} 17$ = trade share (trade [exports + imports] to GDP ratio), v18 $=$ Gini index .

Notes: This is the same table as Table 3a except that the sample does not include observations from oil countries. Extreme-bounds analysis is done by using observations for which the corresponding country belongs to low-income countries at the initial year of the decade. All country/decade observations are used for estimation. The base Beta reports the estimated coefficient of variable from the regression with the variable and the always-included variables (initial income and years of schooling) used as regressors. The high Beta reports the extreme high bound of the estimated coefficient of variable of interest; the low Beta reports the extreme low bound of variable of interest. Other variables are the variables that are included besides the variable of interest and the always-included variables, in producing the extreme bound coefficient. We report variables if they are insignificant at the $5 \%$ level (one sided) less than $10 \%$ of all the sensitivity regressions. NS is the number of regressions where the estimated coefficient is not significant at the $5 \%$ level (one sided). Source: Authors' calculation. 
(b) Entire distribution analysis

\begin{tabular}{|c|c|c|c|c|c|c|}
\hline & Variable & Beta & $\mathrm{df}$ & SD & $\begin{array}{l}\text { Mean of } \\
\text { P-Value }\end{array}$ & $\begin{array}{c}\text { P-Value of the } \\
\text { Mean }\end{array}$ \\
\hline \multirow{3}{*}{ RE } & Work ratio & 0.274 & 58.731 & 0.122 & 0.061 & 0.014 \\
\hline & Lending-to-deposit rate spread & -0.209 & 30.206 & 0.096 & 0.037 & 0.019 \\
\hline & Sex ratio & 0.258 & 58.999 & 0.113 & 0.041 & 0.013 \\
\hline
\end{tabular}

$\mathrm{RE}=$ panel regression with random effects.

Notes: This is the same table as Table $3 \mathrm{~b}$ except that the sample does not include observations from oil countries. Entire distribution analysis is done by using observations for which the corresponding country belongs to low-income countries at the initial year of the decade. Beta, df, and SD are weighted averages of the estimated coefficients, degrees of freedom, and standard deviations, respectively, using the likelihood values as weights in the sensitivity regressions for each variable reported in Table $2 a$. Mean of $p$-value is weighted average of $p$ values; $p$ value of the mean is $p$-value of the average coefficient using the average standard errors that are calculated from the weighted average of estimated variances. We report variables only when the mean of $p$-value or $p$-value of the mean is less than .05 .

Source: Authors' calculation.

\section{Table A4: Countries in the Low- and Middle-Income Class at the Initial Year: Oil Countries Excluded}

\section{(a) Extreme-bounds analysis}

\begin{tabular}{|c|c|c|c|c|c|c|c|c|c|c|}
\hline & Variable & & & SE & t-stat & Obs & Groups & $\mathrm{R}^{2}$ & $\begin{array}{c}\text { Other } \\
\text { Variables }\end{array}$ & NS \\
\hline \multirow{3}{*}{ RE } & \multirow{3}{*}{ Work ratio } & high & 0.519 & [0.177] & 2.93 & 60 & 26 & 0.486 & v3 v12 v13 & \multirow{3}{*}{38} \\
\hline & & base & 0.144 & [0.033] & 4.36 & 475 & 110 & 0.231 & & \\
\hline & & low & -0.263 & [0.169] & -1.56 & 23 & 13 & 0.003 & v6 v10 v12 & \\
\hline
\end{tabular}

$\mathrm{GDP}=$ gross domestic product, $\mathrm{RE}=$ panel regression with random effects, $\mathrm{SE}=$ standard error. $\mathrm{v} 3=$ working-age population growth, $\mathrm{v} 6=$ railway $(\mathrm{km}$ per number of workers), $\mathrm{v} 10$ = lending-to-deposit interest rate spread, $\mathrm{v} 12$ = government debt share (debt-to-GDP ratio), $\mathrm{v} 13=$ conflict index.

Notes: This is the same table as Table 4a except that the sample does not include observations from oil countries. Extreme-bounds analysis is done by using observations for which the corresponding country belongs to either low- or middle-income countries at the initial year of the decade. All country/decade observations are used for estimation. The base Beta reports the estimated coefficient of variable from the regression with the variable and the always-included variables (initial income and years of schooling) used as regressors. The high Beta reports the extreme high bound of the estimated coefficient of variable of interest; the low Beta reports the extreme low bound of variable of interest. Other variables are the variables that are included besides the variable of interest and the always-included variables, in producing the extreme bound coefficient. We report variables if they are insignificant at the $5 \%$ level (one sided) less than $10 \%$ of all the sensitivity regressions. NS is the number of regressions where the estimated coefficient is not significant at the $5 \%$ level (one sided).

Source: Authors' calculation.

\section{(b) Entire distribution analysis}

\begin{tabular}{|c|c|c|c|c|c|c|}
\hline & Variable & Beta & $\mathrm{df}$ & $S D$ & $\begin{array}{l}\text { Mean of } \\
P-V \text { alue }\end{array}$ & $\begin{array}{l}\text { P-Value of } \\
\text { the Mean }\end{array}$ \\
\hline RE & Work ratio & 0.221 & 175.763 & 0.067 & 0.016 & 0.001 \\
\hline
\end{tabular}

$\mathrm{RE}=$ panel regression with random effects.

Notes: This is the same table as Table 4b except that the sample does not include observations from oil countries. Entire distribution analysis is done by using observations for which the corresponding country belongs to middle-income countries at the initial year of the decade. Beta, df, and SD are weighted averages of the estimated coefficients, degrees of freedom, and standard deviations, respectively, using the likelihood values as weights in the sensitivity regressions for each variable reported in Table $2 a$. Mean of $p$-value is weighted average of $p$ values; $p$ value of the mean is $p$-value of the average coefficient using the average standard errors that are calculated from the weighted average of estimated variances. We report variables only when the mean of $p$-value or $p$-value of the mean is less than .05 . Source: Authors' calculation. 
Table A5: Countries in the Middle-Income Class at the Initial Year: Oil Countries Excluded

\section{(a) Extreme-bounds analysis}

\begin{tabular}{ccccccccccc}
\hline & Variable & \multicolumn{2}{c}{ Beta } & SE & t-stat & Obs & Groups & R $^{2}$ & Other Variables & NS \\
\hline \multirow{4}{*}{ RE } & \multirow{2}{*}{ Work ratio } & high & 0.508 & {$[0.076]$} & 6.68 & 79 & 45 & 0.588 & v3 v13v15 \\
& & base & 0.204 & {$[0.035]$} & 5.83 & 284 & 93 & 0.348 & 38 \\
& & low & -0.263 & {$[0.169]$} & -1.56 & 23 & 13 & 0.003 & v6 v10 v12 \\
\hline
\end{tabular}

$\mathrm{FDI}=$ foreign direct investment, $\mathrm{GDP}=$ gross domestic product, $\mathrm{RE}=$ panel regression with fixed effect, $\mathrm{SE}=$ standard error, $\mathrm{v} 3=$ workingage population growth, $v 6$ = railway $(\mathrm{km}$ per number of workers), $\mathrm{v} 10=$ lending-to-deposit interest rate spread, $\mathrm{v} 12$ = government debt share (debt-to-GDP ratio), v13 = conflict index, v15 = accumulated FDI inflows (4 years ahead of each decade).

Notes: This is the same table as Table $5 a$ except that the sample does not include observations from oil countries. Extreme-bound analysis is done by using observations for which the corresponding country belongs to middle-income countries at the initial year of the decade. All country/decade observations are used for estimation. The base Beta reports the estimated coefficient of variable from the regression with the variable and the always-included variables (initial income and years of schooling) used as regressors. The high Beta reports the extreme high bound of the estimated coefficient of variable of interest; the low Beta reports the extreme low bound of variable of interest. Other variables are the variables that are included besides the variable of interest and the always-included variables, in producing the extreme bound coefficient. We report variables if they are insignificant at the $5 \%$ level (one sided) less than $10 \%$ of all the sensitivity regressions. NS is the number of regressions where the estimated coefficient is not significant at the $5 \%$ level (one sided).

Source: Authors' calculation.

\section{(b) Entire distribution analysis}

\begin{tabular}{ccccccc}
\hline & Variable & Beta & df & SD & Mean of $\begin{array}{c}\text { P-Value of } \\
\text { P-Value }\end{array}$ \\
the Mean \\
\hline RE & Work ratio & 0.247 & 114.651 & 0.067 & 0.010 & 0.000 \\
\hline
\end{tabular}

$\mathrm{RE}=$ panel regression with random effects.

Notes: This is the same table as Table $5 \mathrm{~b}$ except that the sample does not include observations from oil countries. Entire distribution analysis is done by using observations for which the corresponding country belongs to middle-income countries at the initial year of the decade. Beta, df, and SD are weighted averages of the estimated coefficients, degrees of freedom, and standard deviations, respectively, using the likelihood values as weights in the sensitivity regressions for each variable reported in Table $2 a$. Mean of $p$-value is weighted average of $p$ values; $p$ value of the mean is $p$-value of the average coefficient using the average standard errors that are calculated from the weighted average of estimated variances. We report variables only when the mean of $p$-value or $p$-value of the mean is less than .05. Source: Authors' calculation. 
Table A6: Countries in the Middle- and High-Income Class at the Initial Year: Oil Countries Excluded

\section{(a) Extreme-bounds analysis}

\begin{tabular}{|c|c|c|c|c|c|c|c|c|c|c|}
\hline & Variable & & & SE & t-stat & Obs & Groups & $\mathbf{R}^{2}$ & Other Variables & NS \\
\hline \multirow{9}{*}{ RE } & \multirow{3}{*}{ Work ratio } & high & 0.422 & {$[0.063]$} & 6.70 & 125 & 64 & 0.550 & v3 v13 v15 & \multirow{3}{*}{0} \\
\hline & & base & 0.212 & {$[0.030]$} & 7.07 & 450 & 105 & 0.317 & & \\
\hline & & low & 0.066 & {$[0.045]$} & 1.47 & 132 & 35 & 0.472 & v11 v12 v18 & \\
\hline & \multirow{3}{*}{$\begin{array}{l}\text { Banking or } \\
\text { currency crisis }\end{array}$} & high & -0.003 & {$[0.005]$} & -0.60 & 137 & 57 & 0.423 & v2 v16 v17 & \multirow{3}{*}{16} \\
\hline & & base & -0.016 & {$[0.004]$} & -4.00 & 241 & 61 & 0.258 & & \\
\hline & & low & -0.027 & {$[0.007]$} & -3.86 & 58 & 36 & 0.291 & v9 v10 v13 & \\
\hline & \multirow{3}{*}{$\begin{array}{l}\text { Accumulated } \\
\text { non-FDI } \\
\text { inflows }\end{array}$} & high & -0.001 & {$[0.006]$} & -0.17 & 111 & 57 & 0.488 & v2 v13 v18 & \multirow{3}{*}{90} \\
\hline & & base & -0.013 & [0.005] & -2.60 & 286 & 98 & 0.172 & & \\
\hline & & low & -0.025 & [0.009] & -2.78 & 81 & 44 & 0.263 & v5 v9 v13 & \\
\hline \multirow{6}{*}{$\mathrm{FE}$} & \multirow{3}{*}{$\begin{array}{l}\text { Banking or } \\
\text { currency crisis }\end{array}$} & high & -0.004 & [0.005] & -0.80 & 141 & 57 & 0.452 & v2 v3 v16 & \multirow{3}{*}{4} \\
\hline & & base & -0.016 & [0.004] & -4.00 & 241 & 61 & 0.510 & & \\
\hline & & low & -0.026 & [0.004] & -6.50 & 55 & 27 & 0.574 & v12 v13 v15 & \\
\hline & \multirow{3}{*}{$\begin{array}{l}\text { Accumulated } \\
\text { non-FDI } \\
\text { inflows }\end{array}$} & high & 0.02 & {$[0.011]$} & 1.82 & 59 & 35 & 0.798 & v10 v11 v13 & \multirow{3}{*}{59} \\
\hline & & base & -0.018 & {$[0.006]$} & -3.00 & 286 & 98 & 0.269 & & \\
\hline & & low & -0.052 & {$[0.018]$} & -2.89 & 123 & 63 & 0.493 & v3 v13 & \\
\hline \multirow{6}{*}{ GMM } & \multirow{3}{*}{$\begin{array}{l}\text { Banking or } \\
\text { currency crisis }\end{array}$} & high & -0.047 & {$[0.077]$} & -0.61 & 122 & 51 & & v2 v8 v16 & \multirow{3}{*}{6} \\
\hline & & base & -0.236 & {$[0.056]$} & -4.21 & 220 & 57 & & & \\
\hline & & low & -0.406 & [0.094] & -4.32 & 53 & 34 & & v8 v10 v13 & \\
\hline & \multirow{3}{*}{$\begin{array}{l}\text { Accumulated } \\
\text { non-FDI } \\
\text { inflows }\end{array}$} & high & 0.086 & {$[0.239]$} & 0.36 & 56 & 34 & & v10 v11 v13 & \multirow{3}{*}{50} \\
\hline & & base & -0.126 & {$[0.021]$} & -6.00 & 265 & 92 & & & \\
\hline & & low & -0.554 & {$[0.287]$} & -1.93 & 42 & 23 & & v10 v12 v13 & \\
\hline
\end{tabular}

$\mathrm{FDI}=$ foreign direct investment, $\mathrm{GDP}=$ gross domestic product, $\mathrm{SE}=$ standard error, $\mathrm{v} 2$ = working-age population share, $\mathrm{v} 3=$ working-age population growth, $\mathrm{v} 5$ = electricity-generating capacity (kilowatt per number of workers), $\mathrm{v} 8=$ domestic credit to private sector (extended by private banks and other financial institutions), $\vee 99$ = bank credit-to-deposit ratio, v10 = lending-to-deposit interest rate spread, v11 = banking or currency crisis (number of years with either banking of currency crises divided by 10 for the decade observations and by 4 for the last period [2010-2014]), v12 = government debt share (debt-to-GDP ratio), v13 = conflict index, v15 = accumulated FDI inflows (4 years ahead of each decade), v16 = accumulated non-FDI inflows (4 years ahead of each decade), v17 = trade share (trade [exports + imports] to GDP ratio), $\mathrm{v} 18=$ Gini index .

Notes: This is the same table as Table 6a except that the sample does not include observations from oil countries. Extreme-bounds analysis is done by using observations for which the corresponding country belongs to middle- or high-income countries at the initial year of the decade. All country/decade observations are used for estimation. RE refers to panel regression with random effects, FE refers to panel regression with fixed effects, and GMM refers to generalized method of moments approach to dynamic panel regression. The base Beta reports the estimated coefficient of variable from the regression with the variable and the always-included variables (initial income and years of schooling) used as regressors. The high Beta reports the extreme high bound of the estimated coefficient of variable of interest; the low Beta reports the extreme low bound of variable of interest. Other variables are the variables that are included besides the variable of interest and the always-included variables, in producing the extreme bound coefficient. We report variables if they are insignificant at the $5 \%$ level (one sided) less than $10 \%$ of all the sensitivity regressions. NS is the number of regressions where the estimated coefficient is not significant at the $5 \%$ level (one sided). Source: Authors' calculation. 


\section{(b) Entire distribution analysis}

\begin{tabular}{clccccc}
\hline \multicolumn{1}{c}{ Variable } & Beta & df & SD & $\begin{array}{c}\text { Mean of } \\
\text { P-Value }\end{array}$ & $\begin{array}{c}\text { P-Value of } \\
\text { the Mean }\end{array}$ \\
\hline \multirow{6}{*}{ RE } & Investment share & 0.051 & 202.073 & 0.023 & 0.041 & 0.015 \\
& Work ratio & 0.217 & 201.999 & 0.046 & 0.001 & 0.000 \\
& Banking or currency crisis & -0.015 & 148.738 & 0.005 & 0.008 & 0.001 \\
& Government debt share & -0.010 & 111.590 & 0.006 & 0.112 & 0.042 \\
& Accumulated non-FDI inflows & -0.009 & 150.709 & 0.004 & 0.025 & 0.025 \\
\hline \multirow{3}{*}{$\mathrm{FE}$} & Work ratio & 0.141 & 66.154 & 0.068 & 0.067 & 0.020 \\
& Banking or currency crisis & -0.015 & 50.639 & 0.005 & 0.007 & 0.002 \\
& Accumulated non-FDI inflows & -0.012 & 62.478 & 0.005 & 0.028 & 0.017 \\
\hline \multirow{2}{*}{$\mathrm{GMM}$} & Banking or currency crisis & -0.202 & 136.308 & 0.072 & 0.008 & 0.003 \\
& Accumulated non-FDI inflows & -0.146 & 139.488 & 0.071 & 0.018 & 0.020 \\
\hline
\end{tabular}

$\mathrm{FDI}=$ foreign direct investment, $\mathrm{FE}=$ panel regression with fixed effects, $\mathrm{GMM}=$ generalized method of moments, $\mathrm{RE}=$ panel regression with random effects.

Notes: This is the same table as Table $6 \mathrm{~b}$ except that the sample does not include observations from oil countries. Entire distribution analysis is done by using observations for which the corresponding country belongs to middle- or high-income countries at the initial year of the decade. Beta, df, and SD are weighted averages of the estimated coefficients, degrees of freedom, and standard deviations, respectively, using the likelihood values as weights in the sensitivity regressions for each variable reported in Table $2 a$. Mean of $p$-value is weighted average of $p$ values; $p$ value of the mean is $p$-value of the average coefficient using the average standard errors that are calculated from the weighted average of estimated variances. We report variables only when the mean of $p$-value or $p$-value of the mean is less than 05 .

Source: Authors' calculation. 


\section{REFERENCES}

Eichengreen, Barry, Donghyun Park, and Kwanho Shin. 2012. "When Fast Growing Economies Slow Down: International Evidence and Implications for China." Asian Economic Papers 11 (1): 42-87.

Feenstra, Robert C., Robert Inklaar, and Marcel P. Timmer. 2015. "The Next Generation of the Penn World Table." American Economic Review 105 (10): 3150-82. www.ggdc.net/pwt

Han, Xuehui, and Shang-Jin Wei. 2015. "Reexamining the Middle-Income Trap Hypothesis: What to Reject and What to Revive?” CEPR Discussion Paper No. 10989.

Lee, Ronald, and Andrew Mason. 2006. "What is the Demographic Dividend?" Finance and Development 43 (3).

Levine, Ross, and David Renault. 1992. "A Sensitivity Analysis of Cross-Country Growth Regressions." American Economic Review 82 (4): 942-63.

Pritchett, Lant, and Lawrence Summers. 2014. "Asiaphoria Meets Regression to the Mean." NBER Working Paper No. 20573.

Reinhart, Carmen, and Kenneth Rogoff. 2009. This Time is Different: Eight Centuries of Financial Folly. Princeton: Princeton University Press.

Rodrik, Dani. 2012. No More Growth Miracles. Project Syndicate. 25 October.

Sala-i-Martin, Xavier. 1997. “I Just Ran Four Million Regressions.” American Economic Review 87 (2): 178-83.

Tornell, Aaron, and Frank Westermann. 2005. Boom-Bust Cycles and Financial Liberalization. Cambridge, MA: MIT Press. 


\section{The Landscape of Economic Growth: Do Middle-Income Countries Differ?}

We review the growth experience of middle-income countries. Economic factors associated with growth appear to differ between middle- and low-income countries. The efficiency of the financial system still appears to matter for the growth of middle-income countries, but less so than in low-income countries; nor are demographic variables as important as before. On the other hand, variables related to macroeconomic stability assume a larger role. These include whether the country experiences a banking or currency crisis, the extent of capital inflows excluding foreign direct investment, and government debt as a share of gross domestic product.

\section{About the Asian Development Bank}

ADB's vision is an Asia and Pacific region free of poverty. Its mission is to help its developing member countries reduce poverty and improve the quality of life of their people. Despite the region's many successes, it remains home to a large share of the world's poor. ADB is committed to reducing poverty through inclusive economic growth, environmentally sustainable growth, and regional integration.

Based in Manila, ADB is owned by 67 members, including 48 from the region. Its main instruments for helping its developing member countries are policy dialogue, loans, equity investments, guarantees, grants, and technical assistance. 